\title{
Molecular Drivers of Platelet Activation: Unraveling Novel Targets for Anti-Thrombotic and Anti-Thrombo-Inflammatory Therapy
}

\author{
Madhumita Chatterjee ${ }^{1}{ }^{(D}$, Agnes Ehrenberg ${ }^{2}$, Laura Mara Toska ${ }^{2}$, Lisa Maria Metz ${ }^{2}$, \\ Meike Klier ${ }^{2}$, Irena Krueger ${ }^{2}$ (D) Friedrich Reusswig ${ }^{2}$ and Margitta Elvers ${ }^{2, *}$ \\ 1 Department of Cardiology and Angiology, Universitätsklinikum Tübingen, Medizinische Klinik III, \\ 72076 Tübingen, Germany; madhumita.chatterjee@med.uni-tuebingen.de \\ 2 Department of Vascular and Endovascular Surgery, Experimental Vascular Medicine, \\ Heinrich-Heine University Medical Center, 40225 Düsseldorf, Germany; agnes.ehrenberg@hhu.de (A.E.); \\ laura.toska@hhu.de (L.M.T.); lisa.metz@hhu.de (L.M.M.); mekli100@uni-duesseldorf.de (M.K.); \\ irena.krueger@uni-duesseldorf.de (I.K.); Friedrich.reusswig@uni-duesseldorf.de (F.R.) \\ * Correspondence: elvers@uni-duesseldorf.de
}

Received: 30 September 2020; Accepted: 22 October 2020; Published: 24 October 2020

\begin{abstract}
Cardiovascular diseases (CVDs) are the leading cause of death globally-partly a consequence of increased population size and ageing — and are major contributors to reduced quality of life. Platelets play a major role in hemostasis and thrombosis. While platelet activation and aggregation are essential for hemostasis at sites of vascular injury, uncontrolled platelet activation leads to pathological thrombus formation and provokes thrombosis leading to myocardial infarction or stroke. Platelet activation and thrombus formation is a multistage process with different signaling pathways involved to trigger platelet shape change, integrin activation, stable platelet adhesion, aggregation, and degranulation. Apart from thrombotic events, thrombo-inflammation contributes to organ damage and dysfunction in CVDs and is mediated by platelets and inflammatory cells. Therefore, in the past, many efforts have been made to investigate specific signaling pathways in platelets to identify innovative and promising approaches for novel antithrombotic and anti-thrombo-inflammatory strategies that do not interfere with hemostasis. In this review, we focus on some of the most recent data reported on different platelet receptors, including GPIb-vWF interactions, GPVI activation, platelet chemokine receptors, regulation of integrin signaling, and channel homeostasis of NMDAR and PANX1.
\end{abstract}

Keywords: platelets; integrins; glycoprotein Ib; glycoprotein VI; reelin; phospholipase D; CXCR; pannexin 1; NMDAR

\section{Introduction}

Cardiovascular diseases (CVDs) include ischemic heart disease, stroke, heart failure, peripheral arterial disease, and a number of other cardiac and vascular conditions. They are the leading cause of death globally. Every year, more people die from cardiovascular disease than any other cause, with $31 \%$ of deaths following cardiovascular diseases worldwide [1-3].

Platelets are small anucleate cells of the hematopoietic system and are formed by megakaryocytes (MKs) in the bone marrow. At sites of vascular injury, platelets adhere to the injured vessel wall, forming a hemostatic plug to avoid excessive blood loss, and therefore play a fundamental role in hemostasis. In contrast, platelets trigger thrombotic events because uncontrolled platelet activation can induce acute vessel occlusion, leading to myocardial infarction or stroke at areas of atherosclerotic plaque rupture $[4,5]$. Ischemic CVDs such as myocardial infarction and stroke as well as infectious 
diseases are characterized by thrombotic and inflammatory events that contribute to both cell death and organ failure. This thrombo-inflammation is mediated by platelets and immune cells such as T cells, macrophages and neutrophils and triggers organ dysfunction [6-8].

Injury of the endothelium leads to exposure of extracellular matrix proteins that serve as substrates for adhesion and activation of circulating platelets. Platelet activation and thrombus formation include different signaling pathways leading to platelet shape change, integrin activation and degranulation. Platelet recruitment to the vessel wall and initial adhesion is dependent on the interaction between glycoprotein (GP) Ib-IX-V and von Willebrand factor (vWF), that binds to subendothelial collagen [9]. In the second step, platelets become activated characterized by shape change, activation of integrins and secretion [10]. In the third step, platelet adhesion to the vessel wall is stabilized followed by platelet aggregation and thrombus formation. These latter processes are mainly mediated by integrins [11], but the mechanisms involved are not fully understood. Thus, many efforts have been made to identify new molecular targets for anti-thrombotic and anti-thrombo-inflammatory therapy in the last years.

\section{GPIb-vWF-Axis}

During vascular injury, subendothelial matrix proteins such as collagen, fibronectin, thrombospondin and endothelial released vWF are exposed to the blood stream. Platelet surface exposed receptors are able to bind to these sub-endothelial matrix components to avoid massive blood loss. A first, transient binding of platelets to the injured vessel wall is achieved by binding of GPIb, exclusively expressed on the platelet surface, to collagen-adherent vWF, thus tethering platelets to the vessel wall. However, binding of GPIb to vWF is characterized by a rapid on-off rate that facilitates binding of the collagen receptor GPVI to fibrillar collagen in the injured vessel wall to initiate platelet activation, firm adhesion and thrombus formation [12]. Under high shear conditions, GPIb-vWF interaction is essential for the recruitment of platelets to the injured vessel wall [5] and initiates intracellular signaling cascades involving tyrosine phosphorylation of SYK, the Src family kinases Lyn and Fyn, and phospholipase (PL) $C \gamma 2$ to induce $\alpha_{\mathrm{IIb}} \beta_{3}$ integrin activation and firm adhesion [13-15]. Thus it is not surprising that inhibition of the GPIb-vWF axis could be a promising target for therapy in ischemic stroke to improve cerebral reperfusion rates and reduce cerebral injury after ischemia and reperfusion as demonstrated by Denorme et al. [16].

\section{Reelin and PLD1 Are New Regulators of GPIb Signaling}

In recent years, different modulators of GPIb activation and signaling have been identified. The glycoprotein reelin has been shown to be important for GPIb-dependent thrombus formation [17]. Reelin was first identified in the central nervous system where it plays a prominent role in brain development by controlling neuronal positioning and migration to mediate the formation of laminated brain structures. It is produced by Cajal-Retzius neurons and interacts with the lipoprotein receptors apolipoprotein E receptor 2 (ApoER2), mediating the formation of filopodia and lamellipodia, and with the very-low-density lipoprotein receptor (VLDLR) [18,19]. Reelin is found in blood plasma and is expressed in endothelia cells, in the liver $[20,21]$ and in megakaryocytes and platelets, where it co-localizes to F-actin and regulates platelet spreading on fibrinogen $[17,22]$. Recent study identified reelin as a new promising therapeutic target to prevent occlusive thrombus formation. Reelin-deficient mice are protected against arterial thrombosis and focal cerebral ischemia but show normal hemostasis. Reelin deficient platelets display reduced adhesion to recombinant vWF under high shear conditions but exhibit no defects in vWF binding under static conditions, when binding of vWF to GPIb is induced by the snake venom botrocetin. After GPIb engagement, integrin activation and the phosphorylation of Erk and Akt are reduced in reelin deficient platelets. Reelin-induced GPIb activation is mediated by the interaction of GPIb and the major platelet reelin receptor amyloid precursor protein (APP) suggesting that reelin-induced effects on GPIb signaling are mediated by APP-GPIb interactions (Figure 1) [17]. 


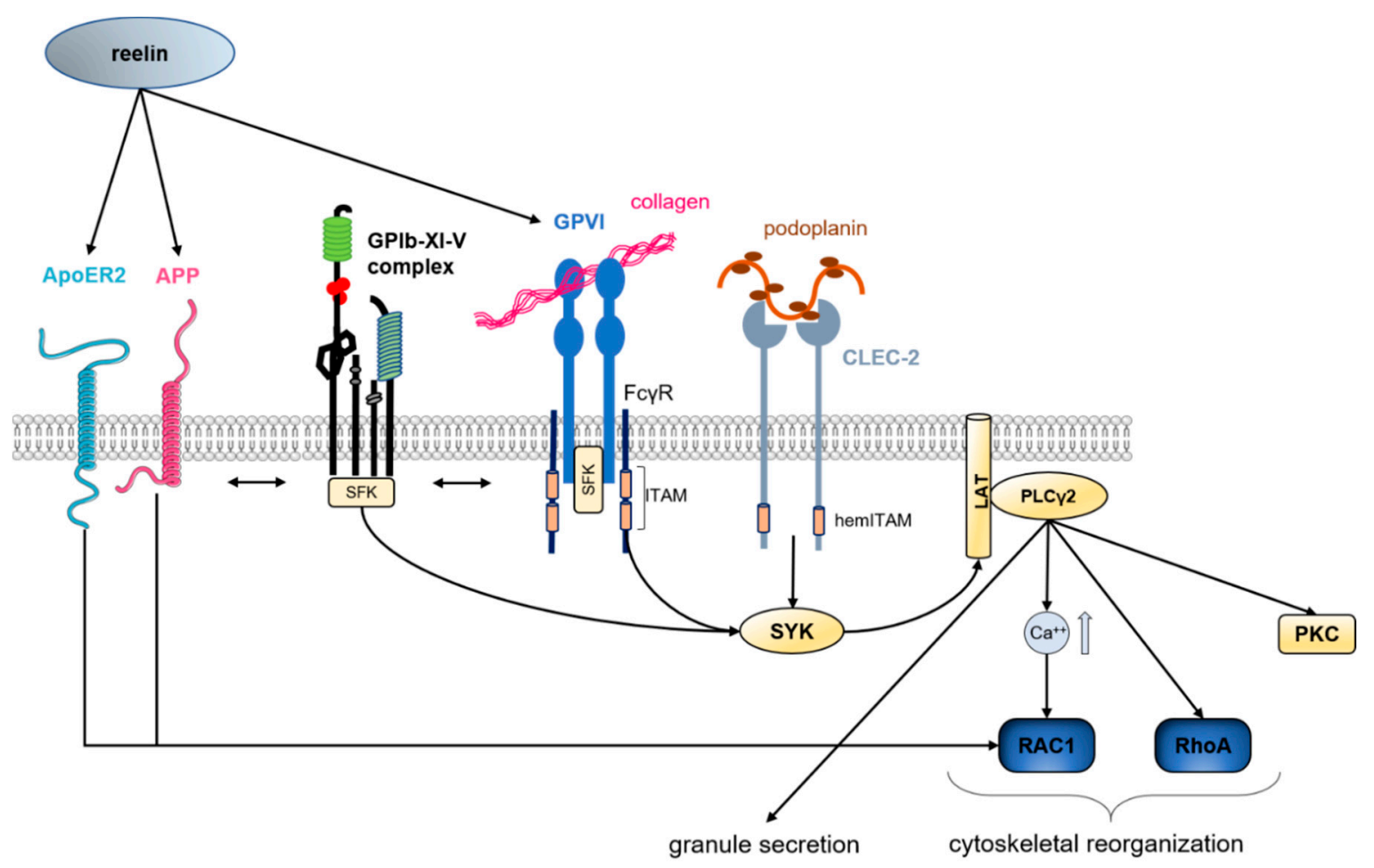

Figure 1. Impact of reelin in platelet activation and ITAM signaling. Extracellular reelin binds to ApoER2 and APP receptors at the platelet surface, resulting in platelet activation through RAC-1 activation. Additionally, reelin binding indirectly modulates GPIb signaling through APP and GPVI. Ligand binding to GPVI leads to dimerization of GPVI monomers, inducing auto-transphosphorylation of the GPVI-associated Fc $\gamma$ R-chain ITAM motif through activation of Src-family kinases (SFKs). Besides, podoplanin binding to the CLEC-2 receptor causes activation of the CLEC-2-integrated hemITAM motif. Phosphorylated ITAM motifs lead to phosphorylation of SYK, which activates LAT kinases, being in direct proximity to PLC $\gamma 2$. Activated PLC $\gamma 2$ causes granule release, activation of protein kinase $\mathrm{C}$ (PKC), and activation of RAC1 and RhoA through calcium influx leading to cytoskeletal reorganization. This figure was created using images from Servier Medical Art Commons Attribution 3.0 Unported License. (http://smart.servier.com). Servier Medical Art by Servier is licensed under a Creative Commons Attribution 3.0 Unported License".

The family of PLD, including the most prominent isoforms PLD1 and PLD2 [23], catalyzes the degradation of phosphatidylcholine into choline and phosphatidic acid (PA) [24], representing a very important messenger in many cellular processes [25]. An important role for PLD1 in GPIb-dependent thrombus formation under flow conditions has been shown using PLD1-deficient mice. Loss of PLD1 in platelets impairs integrin $\alpha_{\mathrm{Ilb}} \beta_{3}$ activation and GPIb-dependent aggregate formation, thereby protecting against thrombosis and ischemic brain infarction without altering hemostasis in PLD1-deficient mice [26]. In contrast, the loss of PLD2 does not affect platelet activation [27,28]. Recent studies provided evidence for yet another important role of PLD1 in platelet-mediated inflammation [29]. According to the prominent role of GPIb in the adhesion of platelets to endothelial cells (ECs) via binding to selectins under high shear rates [30], PLD modulates the up-regulation of endothelial adhesion molecules and regulates the adhesion of platelets to ECs. In addition, PLD1 contributes to platelet-leukocyte recruitment under inflammatory conditions. Thus, PLD1 plays a role in thrombo-inflammatory processes known to aggravate organ damage following ischemia/reperfusion injury after ischemic stroke and myocardial infarction [26,31]. Indeed, in an experimental model of myocardial infarction, loss of PLD1 leads to defective cell adhesion and migration of inflammatory cells into the infarct border zone, and to altered scar formation resulting in enhanced infarct size and declined myocardial function [31]. Recently, a role for PLD2 in platelet-mediated inflammation was identified. PLD2-deficient mice exhibit enhanced 
IL-6 plasma levels concomitant with enhanced migration of inflammatory cells into the infarct border zone $24 \mathrm{~h}$ after acute myocardial infarction. This was due to enhanced integrin $\alpha_{\mathrm{IIb}} \beta_{3}$ activation of PLD2-deficient platelets under inflammatory conditions, resulting in enhanced IL-6 release of ECs to accelerate inflammation after myocardial infarction, suggesting that PLD2 is an effector of thrombo-inflammation [28].

These results emphasize the important role of the vWF-GPIb axis not only in hemostasis and thrombosis but also in thrombo-inflammatory processes following ischemia and reperfusion injury after stroke and myocardial infarction contributing to organ damage. Therefore, the identification of novel modulators of GPIb signaling such as reelin and PLD1 is of utmost interest and might represent promising therapeutic targets to prevent thrombosis and thrombo-inflammation without inducing bleeding complications.

\section{ITAM-Signaling Pathways}

Loss of the immunoreceptor tyrosine-based activation motif (ITAM)-coupled receptors glycoprotein (GP) VI or C-type lectin-like receptor (CLEC)-2 is linked to only a mild bleeding diathesis in patients as well as in mice [32-34]. Both receptors share the conserved immunoreceptor tyrosine-based activation motif (ITAM) sequence containing four amino acids. A tyrosine separated from an (iso)-leucine by two other amino acids, called the YXXL motif. The GPVI/Fc $\gamma$ chain consists of two cytosolic YXXL motifs. In contrast, CLEC-2 consists of only a singular cytosolic YXXL motif, thus named hemITAM [35-37].

\subsection{GPVI Signaling}

GPVI is the major receptor for collagen and is expressed on megakaryocytes and platelets. Surface plasmon resonance studies revealed that fibrous collagen binds to dimeric but not to monomeric GPVI via the glycine-proline-hydroxyproline (GPO) sequence [38]. GPVI activation leads to Src family kinase-mediated phosphorylation of the two ITAMs and induces the binding and phosphorylation of SYK. Phosphorylated SYK in turn induces the phosphorylation of the adaptor protein LAT and the recruitment of different pathway effectors resulting in the activation of PLC $\gamma 2$. The activation of PLC $\gamma 2$ by phosphorylation triggers the mobilization of intracellular $\mathrm{Ca}^{2+}$ stores as well as the activation of PKC. These events lead to the release of intracellular $\alpha$-granules and dense granules and inside-out activation of platelet integrins, resulting in platelet aggregation [37].

In recent years, several GPVI ligands beside collagen have been identified including fibrin, diesel exhaust particles (DEP) and large polysaccharides such as fucoidan and dextran sulfate [39-41]. Interestingly, GPVI was shown to bind to polymerized fibrin to amplify thrombin generation and to recruit additional platelets to the thrombus. Thus, GPVI is a receptor for fibrin, supports phosphatidylserine (PS) exposure and promotes thrombus growth and stability [42].

Since GPVI is a key receptor involved in the pro-thrombotic stage of acute coronary syndrome (ACS) it is presumed to be a useful biomarker for the early detection of atherosclerotic diseases and may contribute to risk stratification and prediction of clinical outcome in patients with ACS [43-47]. Furthermore, soluble GPVI may serve as a target for molecular imaging to identify vulnerable plaques [48]. In addition to the property of GPVI as a diagnostic tool, therapeutic implications have been developed such as the blockage of collagen binding sides of GPVI by a soluble recombinant GPVI-Fc protein. This protein binds to collagen upon vessel injury and avoids binding of platelets via membrane bound GPVI to the injured vessel. Furthermore, anti-GPVI antibodies are useful to block platelet aggregation in static blood [49-54]. Treatment of mice with GPVI-Fc or the bifunctional protein consisting of an stromal cell-derived factor 1 (SDF-1) domain and a GPVI domain (SDF-1-GPVI) preserved cardiac function in a mouse model of myocardial infarction [55,56]. Thus, therapeutic anti-GPVI strategies could serve as a promising strategy for anti-thrombotic and anti-atherosclerotic therapy. 
Reelin Amplifies GPVI Signaling in Platelets

Recently, reelin was identified as a novel regulator of GPVI signaling beside its regulatory role in GPIb signaling and shear-dependent thrombus formation.

Reelin is released after platelet activation with collagen and binds to GPVI with sub-nanomolar affinity in a concentration-dependent manner to amplify GPVI-dependent signaling in platelets [57]. In detail, reelin binding to GPVI induces tyrosine phosphorylation of GPVI target proteins to support platelet binding to collagen and GPVI-dependent RAC1 activation, PLC $\gamma 2$ phosphorylation and platelet aggregation (Figure 1). Antibody-mediated deletion of GPVI from the platelet surface in reelin-deficient mice completely abolishes thrombus formation in vivo. Thrombus formation is only partly reduced in either GPVI-depleted or reelin-deficient mice. Thus, interfering with reelin-GPVI interaction might be a novel strategy to avoid arterial thrombosis [57].

\subsection{CLEC-2 Signaling}

The ability of CLEC-2 monomers to form homodimers is essential for signal transduction. To date podoplanin expressed on lymphatic endothelium and on tumor cells but not on vascular endothelial cells, is identified as the endogenous ligand found for CLEC-2. During podoplanin-mediated platelet aggregation, glycosylated podoplanin interacts with CLEC-2, leading to receptor clustering and phosphorylation of the hemITAM motifs. Moreover, although it is well known that GPVI phosphorylation of the ITAM motif is induced by the Src family kinases (SFK) Fyn and Lyn, it is still controversial how CLEC-2 is initially phosphorylated. Until now, several models of CLEC-2 hemITAM phosphorylation are published. Severin et al., demonstrated that-in contrast to GPVI activation-the tyrosine kinase SYK mediates CLEC-2 phosphorylation independently of the SFKs Fyn, Lyn or Src [58]. In contrast, others postulated that a phosphoinositide 3-kinase (PI3K)/tyrosine-protein kinase Tec (Tec)-axis regulates SYK activation downstream of CLEC-2 [59] and that CLEC-2 phosphorylation is initiated by SFKs. However, once recruited, phosphorylated SYK induces the engagement and phosphorylation of the adaptor protein LAT similar to GPVI. From this point, GPVI and CLEC-2 share the same signaling cascade leading to platelet aggregation and secretion. To date, podoplanin is the only known natural ligand for CLEC-2. However, some studies report increased tail bleeding times and reduced thrombus formation in CLEC-2-deficient mice, suggesting the presence of an additional ligand in the vasculature $[60,61]$.

In the past, different reports provided evidence for GPVI or CLEC-2 to be a major player in platelet-mediated processes of inflammation. Transfer of GPVI or CLEC-2-deficient platelets to thrombocytopenic mice revealed an important role for ITAM-coupled receptors in inflammatory hemostasis of the skin and the lung [36]. In a mouse model of stroke, GPVI was identified as a key player in the processes of neuronal damage following cerebral reperfusion injury [49,62]. Similarly, antibody-mediated deletion of GPVI or treatment of mice with recombinant SDF-1-GPVI reduced inflammation and infarct size demonstrating a pivotal role of GPVI in ischemia reperfusion injury following ligation of the left anterior descending artery (LAD) in a mouse model of myocardial infarction [56,63]. More recently, it was shown that the inhibition of GPVI reduced the adhesion of amyloid beta $(A \beta)$-activated platelets to injured carotid arteries in mice suggesting a role of GPVI in A $\beta$-mediated inflammation in Alzheimer's disease [64].

Only a few studies investigated the role of CLEC-2 in inflammatory processes suggesting that CLEC-2 is a major player in thrombo-inflammatory diseases. Inflammatory events in the vessel wall characterize deep vein thrombosis (DVT) where reduced thrombosis was observed in CLEC-2 deficient mice or after treatment of mice with an anti-podoplanin antibody [65]. So far, there is only experimental evidence for a role of CLEC-2 in thrombo-inflammation in mice. However, Nicolson et al. detected up-regulated podoplanin in the venous valves near to a femoral vein thrombus in a patient with DVT. Interestingly, no alterations in podoplanin expression have been detected in the unaffected valves of the same vein or the equivalent valves in the contralateral leg [66]. 


\section{G-Protein Coupled Receptor Activation-CXCRs as Emerging Modulators}

G-Protein-coupled-receptors (GPCRs) are seven-pass transmembrane receptors that transduce intracellular signals through physical interaction with heterotrimeric G-proteins [67-69], e.g., $G_{s}, G_{i}$, $\mathrm{G}_{\mathrm{q}}$, and $\mathrm{G}_{12 / 13}$, located at the cytoplasmic face of the plasma membrane [70,71]. Platelets express a number of GPCRs that are directly engaged by activating stimuli, protease-activated-receptors (PAR) for thrombin, purinergic receptors-P2Y12, P2Y1 for adenosine diphosphate (ADP), thromboxane receptor (TP) for thromboxane $\mathrm{A}_{2}\left(\mathrm{TxA}_{2}\right)$ or by physiological inhibitors (prostaglandin $\mathrm{I}_{2}$ receptor (IP) for prostaglandin $\mathrm{I}_{2}\left(\mathrm{PGI}_{2}\right)$ [72]) released from the vasculature [67,73]. PAR1 and PAR4 transduce signals through $\mathrm{G} \alpha_{\mathrm{q}}$ and $\mathrm{G} \alpha_{13} ; \mathrm{P} 2 \mathrm{Y}_{1}$ is coupled to $\mathrm{G} \alpha_{\mathrm{q}} ; \mathrm{P} 2 \mathrm{Y}_{12}$ is coupled to $\mathrm{G} \alpha_{\mathrm{i}}$ [74-77], while the $\mathrm{TxA}_{2}$ interacting $\mathrm{TP} \alpha$ receptor is coupled to $\mathrm{G} \alpha_{\mathrm{q}}$ and $\mathrm{G} \alpha_{13}$ in platelets [78]. Therefore, these GPCR are top candidates for therapeutic intervention $[71,73,79]$. On the other end of the spectrum arachidonic acid (AA)-derived $\mathrm{PGI}_{2}$, also called prostacyclin, acts as a physiological anti-platelet agent by engaging $\mathrm{G} \alpha_{\mathrm{s}}$-coupled IP receptor. Prostaglandin $\mathrm{D}_{2}\left(\mathrm{PGD}_{2}\right)$ activates $\mathrm{G} \alpha_{\mathrm{s}}$-coupled prostaglandin $\mathrm{D}_{2}$ receptor $1\left(\mathrm{DP}_{1}\right)$, which triggers the platelet inhibitory adenylyl cyclase-protein kinase A cascade $[69,72,80]$. Prostaglandin E2 $\left(\mathrm{PGE}_{2}\right)$ exhibits a biphasic, dose-dependent effect through $\mathrm{EP}_{1}, \mathrm{EP}_{2}, \mathrm{EP}_{3}$ and $\mathrm{EP}_{4}$ receptors either activating or inactivating platelet response $[67,69,80]$. Recent research in search of novel anti-platelet targets to overcome the challenge of bleeding complications associated with some of the GPCR antagonist in clinical practice (vorapaxar) have revealed some unconventional targets that may fine-tune platelet reactivity.

\section{CXCR Chemokine Receptors on Platelets Fine-Tune Thrombosis}

Platelet chemokine receptors (e.g., C-C chemokine receptor type 1 (CCR1), CCR3, CCR4, CXC receptor 2 (CXCR2), CXCR4, CXCR6 and CXCR7) are a category of GPCRs that aggravate or reduce thrombotic response [81-88] (Figure 2). Platelets derived chemokines, e.g., C-X-C motif chemokine ligand 12 (CXCL12), CXCL16, and the cytokine macrophage migration inhibitory factor (MIF), released upon activation, engage with their cognate receptors and modulate thrombotic attributes, while in a paracrine manner elicit thrombo-inflammatory response from CXCR4, CXCR6, CXCR7 expressing immune and vascular cells [88-93]. Soluble CXCL16, acting through CXCR6 on platelets, triggers the PI3K-Akt activating signaling cascade to substantiate aggregation, degranulation, integrin $\alpha_{\mathrm{IIb}} \beta_{3}$ activation and platelet shape change [88] (Figure 2). Serum levels of CXCL16 are significantly elevated in ACS patients as compared to those with stable angina pectoris (SAP) [94]. They correlate with inflammatory and metabolic risk factors [95], are shown to be prognostically unfavorable $[96,97]$ and independently associated with cardiovascular death and morbidity in ACS patients [98] enrolled in the PLATO (platelet inhibition and patient outcome) trial. Surface expression of scavenger receptor (SR-PSOX/CXCL16) for the atherogenic mediator oxidized low density lipoprotein (oxLDL) on platelets is significantly enhanced in ACS patients and correlates with the circulatory inflammatory marker C-reactive protein (CRP) and creatinine kinase (CK) [99]. CXCL16 is abundantly deposited on inflammatory atherosclerotic plaques and carotid endarterectomy specimens and promotes CXCR6-dependent platelet adhesion to the inflamed endothelial cells and vWF [100], suggesting its potential to propagate thrombo-inflammation.

The Gi-coupled canonical CXCR4 and atypical/non-canonical CXCR7 are platelet receptors for the pro-inflammatory chemokine SDF-1 $\alpha /$ CXCL12 and the chemokine-like cytokine MIF, whereas interferon inducible T cell alpha chemoattractant (ITAC, also named CXCL11) exclusively ligates CXCR7 [101,102] (Figure 2). Moreover, the presence of ligands in the immediate microenvironment influences a dynamic alteration in CXCR4/CXCR7 surface expression in platelets [101,102]. Platelet CXCR4/CXCR7 surface expression is significantly elevated in coronary artery disease (CAD) patients and influences prognosis [87] following myocardial infarction (MI) $[86,87,103]$. Mechanistic insights reveal the functional dichotomy of CXCR4 and CXCR7 in substantiating thrombotic response through CXCR4, whereas a pro-survival and anti-thrombotic impact was observed through CXCR7 [101,103]. MIF does not alter degranulation, ADP- or TxA2-analog (U46619)-induced aggregation or spreading on 
fibrinogen $[91,92,101]$, either alone or synergistically in combination with other agonists. However, the pro-survival effect of MIF-CXCR7, significantly attenuates the exposure of thrombogenic phospholipid phosphatidylserine and counteracts thrombus build up [101] (Figure 2). On the contrary, CXCL12/SDF-1 acting through Gi-coupled CXCR4 clearly exerts a pro-thrombotic impact (Figure 2). Platelets exhibit flow directed migration towards CXCL12/SDF-1 [104] and also transmigrate through endothelium following a CXCL12 gradient, attributed to CXCR4 [105]. Once in a CXCL12/SDF-1 enriched microenvironment, e.g., atherosclerotic plaques, the CXCL12/CXCR4-Gi axis in platelets triggers intracellular calcium mobilization, PI3K activation, while dampening platelet inhibitory cAMP levels, leading to augmented aggregation [7,13-17,106-109] and thrombotic potential (Figure 2). SDF- $1 \alpha$-CXCR4 localized to lipid rafts in the platelet membrane trigger platelet reactivity [110], while decreased surface expression of CXCR4 in patients with inherited thrombocytopenia corroborates with impaired CXCL12/SDF1 $\alpha$-triggered platelet aggregation [111]. CXCL12 induces the primary phase of aggregation at lower concentrations, but dose dependently instigates a biphasic aggregation profile involving PI3K and prostanoids [107]. CXCL12 also synergistically substantiates aggregation induced by sub-threshold concentration of ADP and thrombin [108] and relatively weaker agonist serotonin (5HT), an effect substantiated by granular release (ADP, adenosine triphosphate (ATP)) [109], P-selectin exposure [108], PLC activation, and release of TxA 2 [109]. CXCL12 increases platelet adhesion to collagen type IV and fibrinogen, an effect counteracted by apyrase [108] and mediated through ATP release, $\mathrm{TxA}_{2}$ production, promoting aggregation and thrombus formation $[109,112]$, in contrast to the anti-thrombotic influence of MIF [101] (Figure 2).

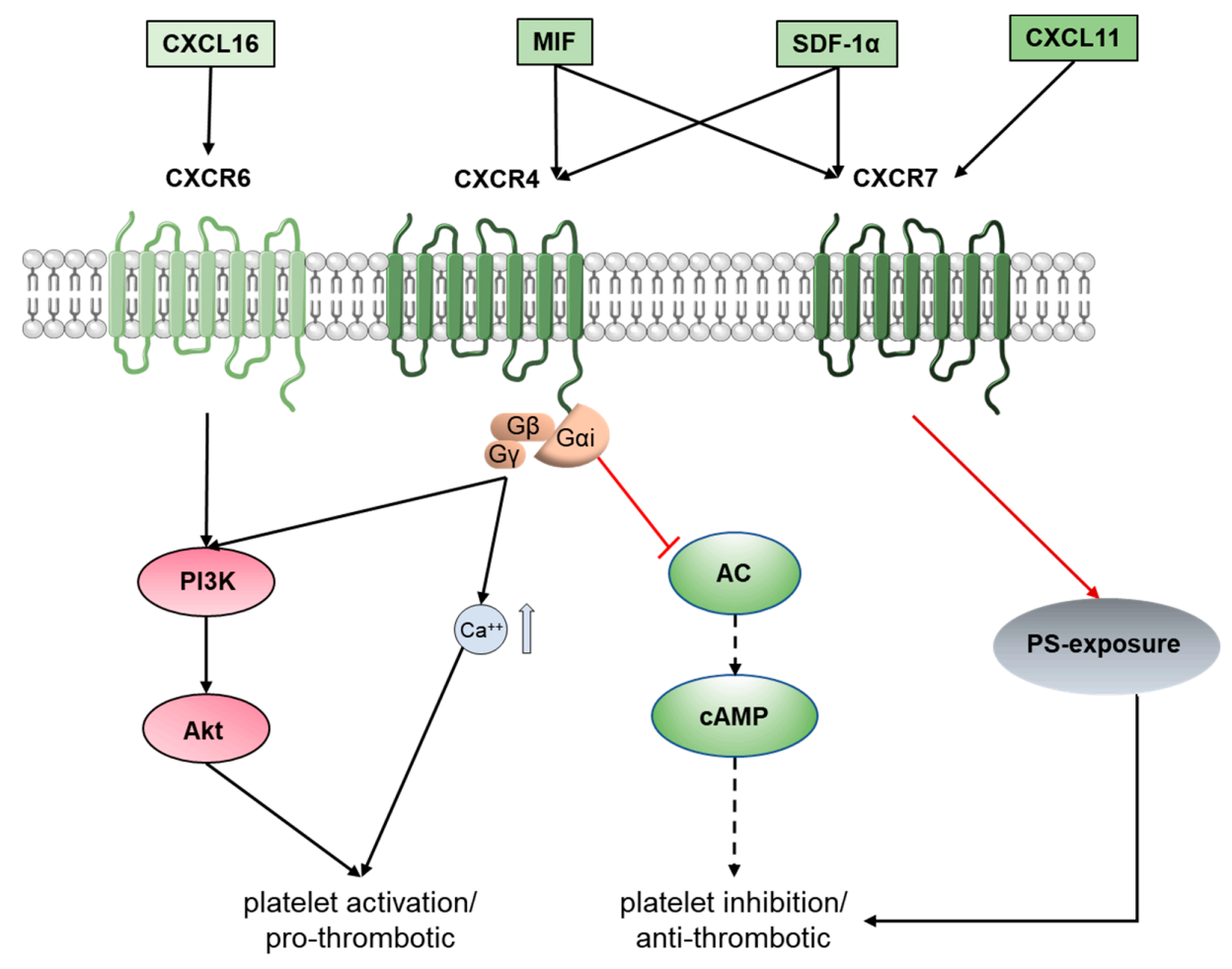

Figure 2. Regulation of platelet activation by CXCR chemokine receptors. Different chemokine receptors like CXCR6, CXCR4 and CXCR7 induce GPCR signaling in platelets. The chemokines CXCL16, and CXCL12/SDF-1 $\alpha$ activate the phosphatidylinositol 3-kinases (PI3K) pathway leading to the activation of protein kinase $\mathrm{B}(\mathrm{Akt})$ and calcium mobilization resulting in platelet activation. Simultaneously, AC is inhibited through G $\alpha$ i downstream of CXCR4 ligation by CXCL12/SDF-1 $\alpha$. MIF binding to CXCR7 substantiates platelet survival through PI3K-Akt pathway and downregulates phosphatidyl serine (PS) exposure. This figure was created using images from Servier Medical Art Commons Attribution 3.0 Unported License. (http://smart.servier.com). Servier Medical Art by Servier is licensed under a Creative Commons Attribution 3.0 Unported License". 
Plasma levels of CXCL12/SDF1 $\alpha$ [113] and MIF [114] are elevated in ACS patients and associated with progressive disease severity, which may influence platelet responsiveness differentially through CXCR4/CXCR7. Platelet CXCR4 surface expression correlates inversely whereas CXCR7 correlates positively with inflammatory and atherogenic oxLDL in platelets from CAD patients. CXCR4 and CXCR7 also mediate the synergistic effects of pro-inflammatory CXCL12 on LDL and oxLDL induced changes to platelet morphodynamics and functional response [112], highlighting the potential of CXCL12/CXCR4/CXCR7 in executing thrombo-inflammatory platelet functions in a hyperlipidemic environment to promote atheroprogression. Differences in release kinetics and specific trigger for secretion may direct the course and pattern of functional impact exerted by different chemokines on platelet response as they engage CXCR6, CXCR4, or CXCR7. These GPCRs may provide promising therapeutic alternatives to check thrombotic functions without compromising the hemostatic and regenerative capacity of platelets.

\section{Integrin Signaling in Platelets}

\subsection{Integrin Structure}

Integrins are heterodimeric transmembrane proteins expressed on the cell surface of different cells. They serve as adhesion receptors that trigger intracellular signaling pathways by binding extracellular ligands [115]. Integrins are composed of two non-covalently bound subunits $[115,116]$. Overall, there are eight $\beta$ - and $18 \alpha$-chains known. Through different combinations of these various subunits, 24 integrins have been identified in mammals that can bind a variety of adhesion ligands [117,118]. Due to their function as adhesion receptors, integrins mediate the adhesion to the extracellular matrix and between cells. Therefore, they are involved in processes like cell differentiation, proliferation, and migration in organisms, as well as in platelet adhesion and aggregation $[115,117,119]$.

Five different integrins are described at the platelet surface. The classification of these integrins is based on the different $\beta$-subunits. There are three $\beta_{1}$ - and two $\beta_{3}$-class integrin receptors exposed at the platelet surface. Members of the $\beta_{1}$-class integrin receptors are the collagen receptor $\alpha_{2} \beta_{1}$, the fibronectin receptor $\alpha_{5} \beta_{1}$ and the laminin receptor $\alpha_{6} \beta_{1}$. The fibrinogen receptor $\alpha_{\text {IIb }} \beta_{3}$ and the vitronectin receptor $\alpha_{\mathrm{v}} \beta_{3}$ correspond to the $\beta_{3}$-class integrin receptors (Table 1) [118].

Table 1. Platelet integrins with classification, glycoprotein (GP) nomenclature and corresponding ligands.

\begin{tabular}{cccc}
\hline Classification & Integrin & GP Nomenclature & Ligands \\
\hline \multirow{3}{*}{$\beta$ 1-class } & $\alpha_{2} \beta_{1}$ & GPIa/IIa & collagen \\
& $\alpha_{5} \beta_{1}$ & GPIc/IIa & fibronectin \\
& $\alpha_{6} \beta_{1}$ & GPIc/IIa & laminin \\
& & & fibrinogen, \\
& & fibronectin, \\
& & thrombospondin, \\
33-class & $\alpha_{\mathrm{IIb}} \beta_{3}$ & GPIIb/IIIa & vitronectin, \\
& & & von Willebrand factor \\
& & vitronectin, \\
& & fibrinogen, \\
& & fibronectin, \\
& & collagen, \\
& & GP $\alpha \mathrm{v} / \mathrm{III}$ & osteopontin, \\
& & & thrombospondin, \\
& & & von Willebrand factor \\
\hline
\end{tabular}

The most redundant and prominent integrin receptor on platelets is the fibrinogen receptor integrin $\alpha_{\mathrm{IIb}} \beta_{3}$ (also known as GPIIb/IIIa). About 80,000 of these glycoprotein complexes can be found in their inactive state on the surface of resting platelets [120]. Furthermore, the membrane of $\alpha$-granules expresses $\alpha_{\mathrm{IIb}} \beta_{3}$ integrins. Activation-induced secretion of $\alpha$-granules leads to externalization of $\alpha_{\mathrm{IIb}} \beta_{3}$ 
integrins at the platelet surface and serves as a marker of platelet activation [121]. Rare mutations in the integrin subunits have been shown to modify the interaction between the subunits of the integrin. This connection is formed by a salt bridge that links the intracytoplasmic part of $\alpha \mathrm{Ill} b$ to the $\beta 3$ unit of the $\alpha_{\mathrm{IIb}} \beta_{3}$ integrin. Mutations in the salt bridge cause abnormal proplatelet formation with abnormal large $\alpha$-granules and reduced but not absent platelet aggregation [122].

\subsection{Bidirectional Signaling of Integrin $\alpha_{I I b} \beta_{3}$ : Role of Paxillin, Reelin and PLD1}

In the plasma membrane of platelets, integrin $\alpha_{\mathrm{IIb}} \beta_{3}$ serves as bidirectional receptor for inside-out and outside-in signaling [115]. The inside-out signaling is induced by binding of different soluble or immobilized agonists to platelets (e.g., thrombin, $\mathrm{ADP}, \mathrm{TxA}_{2}$, epinephrine, vWF, collagen, etc.) via GPCRs or GPs such as GPIb or GPVI at the platelet membrane. Platelet activation triggers intracellular signaling cascades that lead to a conformational change of integrin $\alpha_{\mathrm{IIb}} \beta_{3}$ [117]. The binding of the intracellular protein talin to the cytoplasmic part of integrin $\alpha_{\mathrm{IIb}} \beta_{3}$ results in an unclasping of the cytoplasmic and transmembrane domain of $\alpha_{\mathrm{IIb}}$ and $\beta_{3}$. This unclasping finally triggers a conformational change of the extracellular domain. The talin-triggered conformational change of integrin $\alpha_{\mathrm{IIb}} \beta_{3}$ is supported by the interaction of kindlin and the C-terminal region of the $\beta 3$ cytoplasmic domain [123-125]. Investigating the mechanistic details, Gao et al. recently showed that kindlin directly interacts with paxillin. The disruption of this binding through mutations in the binding site significantly impaired the activation of integrin $\alpha_{\mathrm{II}} \beta_{3}$. This suggests that the interaction between kindlin and paxillin supports talin-mediated integrin $\alpha_{\mathrm{IIb}} \beta_{3}$ activation that could be a target for anti-thrombotic therapies [126]. The conformational change of the $\alpha_{\mathrm{IIb}} \beta_{3}$ integrin activates the receptor from its inactive into its active state [115]. This activation drives binding of ligands with higher affinity (Figure 3) [117]. Fibrinogen as major ligand binds to $\alpha_{\mathrm{IIb}} \beta_{3}$ via its HHLGGAKQAGV sequence that is located in the C-terminus of the $\gamma$-chain of fibrinogen and the RGD sequence in the $\alpha$-chain of integrin $\alpha_{\mathrm{IIb}} \beta_{3}$. Since the RGD sequence can be found in other proteins, such as vitronectin, fibronectin, and von Willebrand factor, it is not surprising that these proteins are ligands that can be bound to $\alpha_{\mathrm{IIb}} \beta_{3}$ integrin as well [125].

The binding of ligands to the extracellular domain of integrin $\alpha_{\mathrm{IIb}} \beta_{3}$ induces integrin clustering and promotes integrin outside-in signalling [115]. Integrin outside-in signaling triggers a set of intracellular processes like platelet spreading, cytoskeleton reorganization, clot retraction, granule secretion as well as platelet adhesion and aggregation that finally leads to thrombus formation and stabilization [127]. During integrin $\alpha_{\mathrm{Ib}} \beta_{3}\left(\alpha_{5} \beta_{1}\right.$ and $\left.\alpha_{2} \beta_{1}\right)$-mediated platelet adhesion, the protein disulfide isomerase (PDI) inherits an important role as enzymatic mediator for disulfide exchange [128]. Lahav et al. could show that specific blockers of PDI inhibit the aggregation of platelets [129]. In mice, quercetin-3rutinoside block platelet accumulation as well as fibrin generation at the vascular injury site [130]. In patients who are at risk of thrombosis, quercetin flavonoids inhibit PDI activity in plasma and reduce platelet-dependent thrombin generation [131].

Regulation of integrin $\alpha_{\mathrm{IIb}} \beta_{3}$ outside-in signaling involves different interacting proteins, which associate with the cytoplasmic tails of $\alpha_{\mathrm{IIb}} \beta_{3}$. The tyrosine kinase c-Src comes into proximity to the active cytoplasmic tail of the $\beta_{3}$ integrin subunit to induce full catalytic activation by trans-autophosphorylation to initiate outside-in signaling $[127,132]$. This is followed by coordinated interactions of Csk, Src, and SYK kinases with integrin $\alpha_{\mathrm{IIb}} \beta_{3}$ to induce integrin signaling finally resulting in cytoskeletal reorganization [133]. Furthermore, a Src-kinase-dependent activation of PLC $\gamma 2$ and phosphorylation of MLC mediates clot retraction downstream of integrin $\alpha_{\mathrm{IIb}} \beta_{3}$ [134]. Enhanced integrin $\alpha_{\mathrm{II}} \beta_{3}$ outside-in signaling was observed in mice with a gain-of-function mutation in PLC $\gamma 2$ [135]. Platelets from these mice show accelerated spreading on different matrices and elevated clot retraction suggesting a major role for PLC $\gamma 2$ in integrin outside-in signaling. 

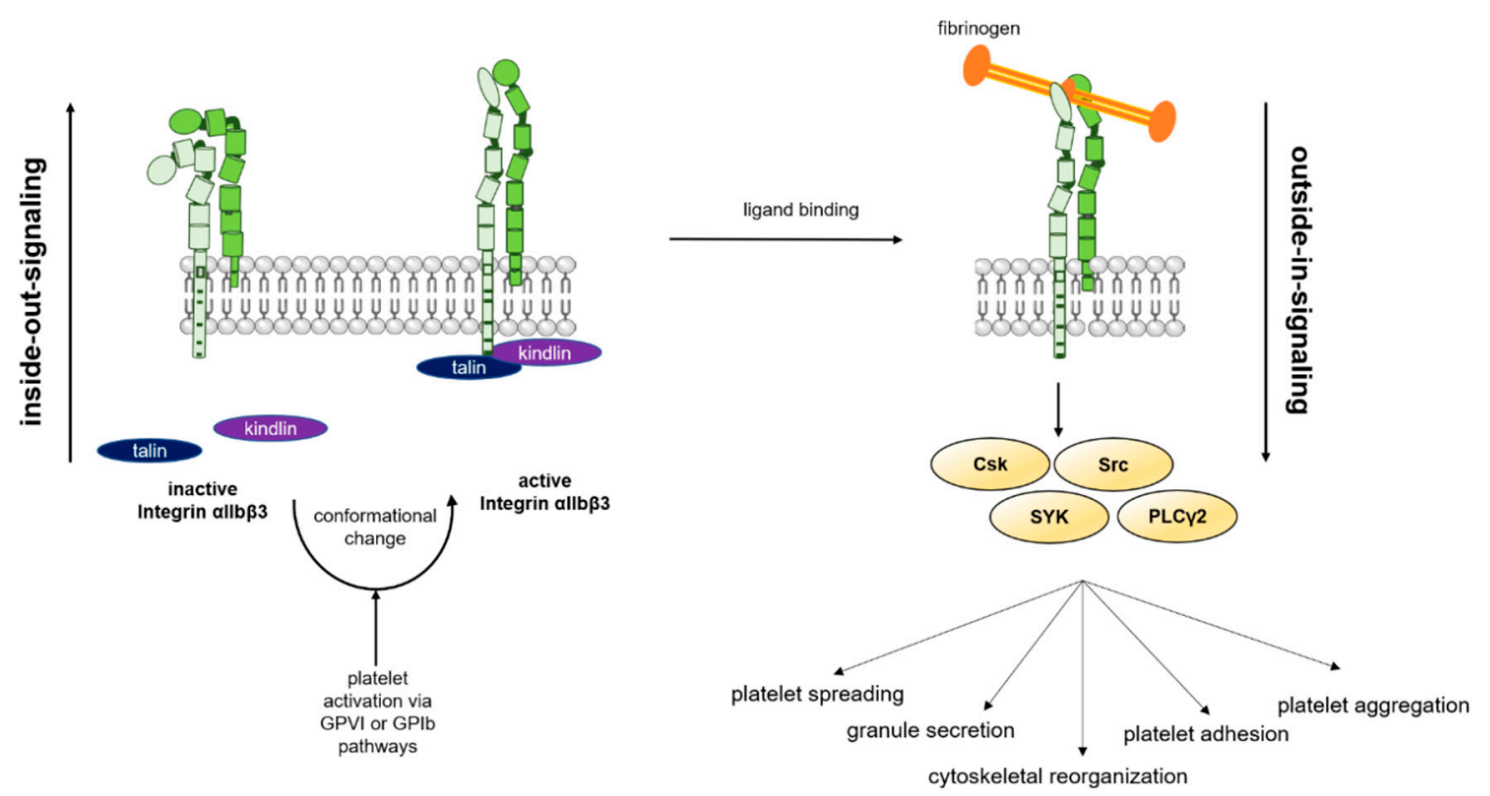

Figure 3. Inside-out- and outside-in-signaling of integrin $\alpha_{\operatorname{IIb}} \beta_{3}$. In resting platelets, integrin $\alpha_{\operatorname{IIb}} \beta_{3}$ is in an inactive conformation that prevents ligand binding. However, an initial activation of platelets (e.g., via GPIb or GPVI signaling) leads to binding of cytosolic kindlin and talin. This binding induces a conformational change of integrin $\alpha_{\mathrm{IIb}} \beta_{3}$ that allows the binding of fibrinogen and other ligands. The process which induces the conformational change of integrin $\alpha_{\mathrm{IIb}} \beta_{3}$ is called inside-out signaling. Binding of a ligand like fibrinogen to the extracellular domain of integrin $\alpha_{\mathrm{IIb}} \beta_{3}$ triggers a signaling cascade through various kinases. This amplifies different platelet processes such as spreading, granule secretion and aggregation. The process of extracellular ligand-induced activation of integrin $\alpha_{\mathrm{IIb}} \beta_{3}$ is called outside-in signaling. This figure was created using images from Servier Medical Art Commons Attribution 3.0 Unported License. (http://smart.servier.com). Servier Medical Art by Servier is licensed under a Creative Commons Attribution 3.0 Unported License".

Based on the finding that ibrutinib can inhibit platelet integrin $\alpha_{\mathrm{IIb}} \beta_{3}$ outside-in signaling, Dobie and colleagues investigated the effects of this inhibitor on platelet activation and glycoprotein expression in more detail by [136]. Ibrutinib induced the shedding of integrin $\alpha_{\mathrm{IIb}} \beta_{3}$ from the platelet surface in a time- and dose-dependent manner as detected by reduced integrin $\alpha_{\mathrm{IIb}} \beta_{3}$ surface expression of platelets isolated from patients with chronic lymphocytic leukemia, who were treated with ibrutinib. The underlying molecular mechanisms including the responsible sheddases are still unknown [137]. PLD1 modulates platelet $\alpha_{\mathrm{IIb}} \beta_{3}$ integrin activation; therefore reduced shear-dependent thrombus formation in PLD1-deficient mice was observed [26]. More recently, Klier et al., could show reduced platelet adhesion to endothelial cells caused by defective integrin activation confirming a role for PLD1 not only in hemostasis and thrombosis but also in platelet-mediated inflammation [29]. Analyzing the impact of reelin signaling in platelets and its role for integrin activation and thrombus formation, Gowert et al. showed that reelin is a mediator of GPIb-dependent integrin activation as well [17]. In contrast to cytoplasmic PLD1 that affects integrin signaling by the activation of Src [29], reelin binds to its main receptor APP at the platelet surface leading to the co-localization of APP and GPIb to induce integrin activation. However, the molecular mechanisms behind the impact of reelin on integrin activation are not entirely clear to date.

\section{Polymorphonuclear Leukocyte Released Platelet Agonists}

Activated platelets release pro-inflammatory chemokines and cytokines and show an increased expression of P-selectin and CD40-ligand on their surface. These platelets are able to interact with leukocytes and endothelial cells leading to the recruitment of neutrophils into the inflamed tissue [138]. 
Interaction of polymorphonuclear leukocytes (PMNLs) with platelets is important for host defense and is associated with an increased risk of thrombosis induced by inflammatory pathways. The ability of PMNLs to release antimicrobial peptides, so called human neutrophil peptides (HNPs) or $\alpha$-defensins, is an important mechanism of the immune response. Once released, HNPs are able to destroy microorganism membranes to exhibit their antimicrobial activity [139]. Besides their role in host defense, it was shown that HNPs act as platelet agonists, leading to platelet degranulation and even shedding of microparticles. Horn et al. showed that HNPs are able to induce platelet apoptosis by the formation of amyloid-like structures. Moreover, HNPs induce the formation of polymeric fibrinogen and thrombospondin-1 structures where platelets adhere and form aggregates. Furthermore, microorganisms are captured by these amyloid-like structures thus linking thrombosis and infection. Blocking of integrin $\alpha_{\mathrm{IIb}} \beta_{3}$ (GPIlb/IIIa) strongly inhibits HNP-induced activation of platelets [140].

Recently, it was shown that transgenic mice expressing human $\alpha$-Def-1 $\left(\operatorname{Def}^{++}\right)$developed larger occlusive neutrophil-rich clots after ligation of the inferior vena cava (IVC), characterized by abnormal fibrin networks. Moreover, these mice were resistant to thrombo-prophylactic treatment with heparin. The inhibition of HNP synthesis or release was able to rescue this phenotype showing smaller thrombi and restoration of the responsiveness to heparin [141].

These observations explain an increased thrombotic risk at sites of inflammation and provide further insights into mechanisms linking inflammation to thrombosis. Glycosaminoglycans and serpins, which are potent inhibitors of platelet activation by HNPs, should be evaluated for therapeutic use in diseases characterized by activated hemostasis and inflammation [140]. Furthermore, drugs that inhibit neutrophil degranulation could be useful to treat or prevent thrombosis that develop during systemic inflammation with enhanced neutrophil activation [141].

\section{Ion Channels: N-methyl-d-aspartate Glutamate Receptor (NMDAR) and Pannexin-1 (PANX1) as Modulators of Platelet Function}

Ion homeostasis in each cell is a fundamental regulator of cellular functions and protection against apoptosis. In the last decades, the role of different ions was extensively investigated and $\mathrm{Ca}^{2+}$ was identified as a critical second wave mediator in different cell types [142]. Platelet activation in response to different agonists trigger different signaling pathways to mobilize cytosolic $\mathrm{Ca}^{2+}$ [143]. This process is essential for the reorganization of the cytoskeleton, the so called shape change [144]. Rapid increase in cytosolic $\mathrm{Ca}^{2+}$ is mediated by two main sources: (i) release of $\mathrm{Ca}^{2+}$ by an endomembrane system called dense tubular system (DTS) or (ii) by entry of $\mathrm{Ca}^{2+}$ through the plasma membrane [145]. Moreover, recent studies provide evidence that acidic organelles such as lysosomes are involved in the uptake and release of $\mathrm{Ca}^{2+}$, proposing a role for acidic organelles in platelet-mediated $\mathrm{Ca}^{2+}$ signaling [146]. Here, we focus (i) on the N-methyl-d-aspartate glutamate receptor (NMDAR) on the platelet membrane as well as (ii) on pannexin-1 (PANX1), an ion channel that mediates platelet activation and thrombus formation and how they potentially interact to mediate platelet responses.

\subsection{N-methyl-d-aspartate Glutamate Receptor (NMDAR)}

The N-methyl-d-aspartate glutamate receptor (NMDAR) belongs to the ionotropic glutamate receptor family and functionally consists of a heterotetramer or heteropentamer. Each receptor is composed of the essential NMDA receptor 1 (GluN1) subunit, a various number of NR2 subunits: GluN2A, GluN2B, GluN2C and GluN2D [147] and rarely GluN3 (A and B) subunits [148]. NMDAR plays a critical role in neuronal signaling and are activated by binding of its main agonists L-glutamate and glycine to the GluN1 and GluN2 subunit. Ligand-gated opening removes the $\mathrm{Mg}^{2+}$ plug which finally leads to $\mathrm{Ca}^{2+}$ exchange to maintain $\mathrm{Ca}^{2+}$ homeostasis [149].

Platelets store about $400 \mu \mathrm{M}$ glutamate in their dense granules which is released upon platelet activation and aggregation [150]. High extracellular glutamate concentrations lead to $\mathrm{Na}^{+}$influx mediated by $\alpha$-amino-3-hydroxy-5-methyl-4-isoxazolepropionic acid (AMPA) and kainite receptors contributing to membrane depolarization [150]. This process might enable L-glutamate binding to the 
GluN1 and GluN2 subunit to remove the $\mathrm{Mg}^{2+}$ plug leading to NMDAR activation and increased $\mathrm{Ca}^{2+}$ conduction in platelets (Figure 4).

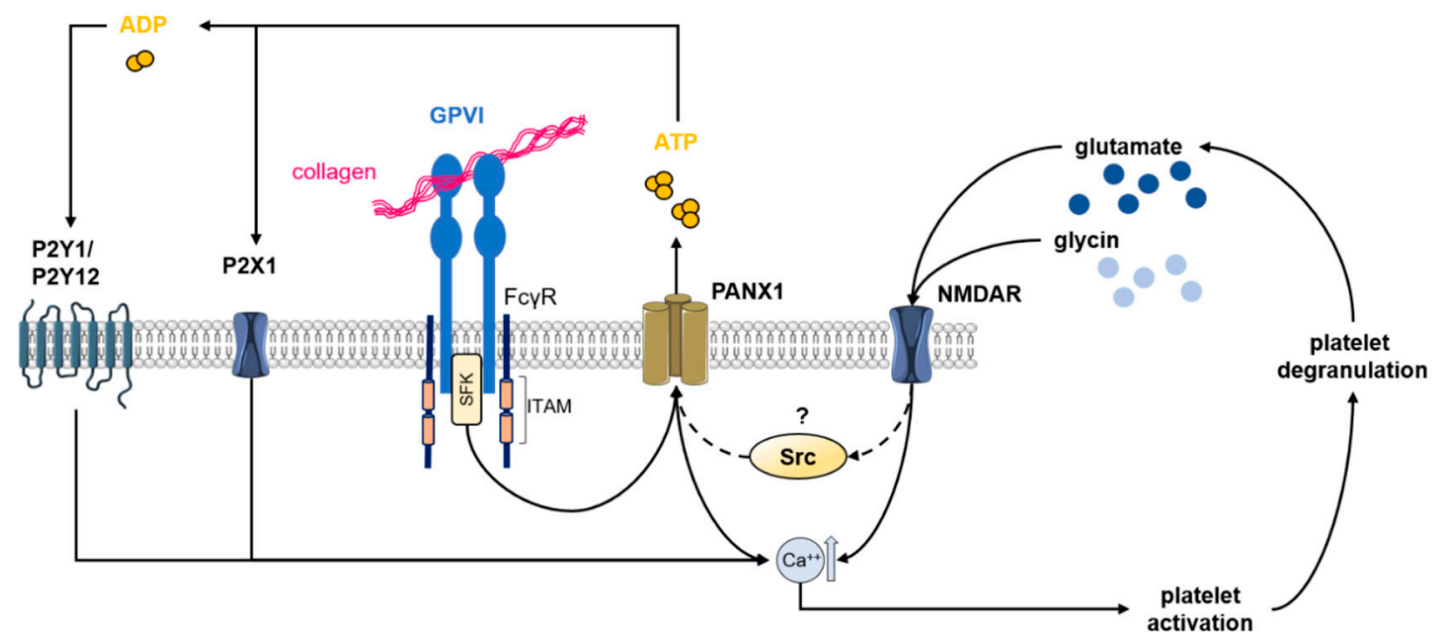

Figure 4. PANX1 and NMDAR activation upon platelet activation and signaling. Collagen binding induces activation of Src-family kinases (SFKs) which in turn activates PANX1 channels. Activation of PANX1 leads to an exchange of calcium and ATP, both modulating platelet activation through intra-and extracellular pathways. ATP directly binds to P2X1 or is degraded to ADP and binds to the purineric receptors P2Y1/P2Y12, all inducing platelet activation. Additionally, NMDAR might influence PANX1 activation through Src kinases, but this remains unclear in platelets to date. Besides, NMDAR activation induces calcium mobilization resulting in platelet activation. In a feedback loop, activated platelets release glutamate, an essential ligand for NMDAR activation. This figure was created using images from Servier Medical Art Commons Attribution 3.0 Unported License. (http://smart.servier.com). Servier Medical Art by Servier is licensed under a Creative Commons Attribution 3.0 Unported License".

Using immunocytochemistry, the group of Genever first described the expression of the initial GluN1 subunit on the platelet surface, but their function remains unclear [151]. In 2004, Kalev-Zylinska and colleagues identified the four subunits: GluN1, GluN2A, GluN2D and GluN3A that form the NMDARs on the platelet surface. Interestingly, the fully functional receptor complex is transported to the plasma membrane after platelet activation. This supports the hypothesis of a potential role of NMDARs in platelet mediated aggregation and thrombus formation [152]. However, human platelet aggregation was only slightly reduced in the presence of the NMDAR antagonist MK-801. A few years later, the same group demonstrated a role of NMDARs in promoting dense granule release, thrombus formation and stabilization, using an inhibitory antibody against the GluN1 subunit [153]. These data provide evidence that NMDARs might be involved in $\mathrm{Ca}^{2+}$ homeostasis upon platelet aggregation and thrombus formation. However, $\mathrm{Ca}^{2+}$ measurements with platelets from GluN1 knock-out mice have to be performed in the near future to clarify the role of NMDARs in intraplatelet calcium homeostasis and thrombotic responses.

\subsection{Pannexin-1 (PANX1)}

20 years ago a new subgroup of transmembrane proteins, called pannexins (PANX1, PANX2 and PANX3), were identified in many mammalian tissues [154]. PANX1 is ubiquitously expressed, whereas PANX2 is mostly found in the central nervous system (CNS) and PANX3 in bone and skin [155]. All three isoforms function as ion channels for small molecules with a high affinity for ATP. In 2014, Taylor and colleagues identified transcripts for PANX1, but not PANX2 and PANX3 in human platelets. Immunochemistry analysis revealed that PANX1 is predominantly located on the surface of platelets. Targeting PANX1 channels by probenecid (Prb) in vitro revealed that platelet activation upon stimulation with low concentrations of collagen induces opening of PANX1 
channels and thereby amplifies $\mathrm{Ca}^{2+}$ influx and aggregation by activation of the P2X1 channel [156,157]. The activation of PANX1 channels via collagen is mediated by GPVI, leading to the phosphorylation of SFKs (Figure 4) [157]. Inhibition of SFKs reduces PANX1-dependent platelet aggregation as well as intracellular phosphorylation of PANX1 at Tyr308 [158]. Ex vivo thrombus formation on collagen under arterial shear rates is reduced when whole blood is treated with Prb [156]. More recently, the impact of platelet PANX1 in thrombosis and hemostasis has been confirmed using platelet-specific PANX1 knockout mice (Panx1(fl/fl)/PF4-cre+) that display extended bleeding times and defective arterial thrombosis in vivo [158].

In neuronal tissue, activated NMDARs cross-activate PANX1 through phosphorylation of SFKs [159]. Moreover, inhibiting Src kinase-mediated phosphorylation of PANX1 at Tyr308 blocks metabotropic NMDAR signaling in brain slices. Furthermore, disturbing the NMDAR-Src-PANX1 complex has been found to be neuroprotective after ischemia or stroke, suggesting that the NMDAR-PANX1 axis might be involved in thrombo-inflammation [160].

\section{Conclusions}

The high burden of CVDs and the impact of platelets in thrombotic and thrombo-inflammatory processes indicate a high medical need for effective and novel anti-thrombotic and anti-thromboinflammatory therapies that avoid thrombotic and inflammatory events while preserving hemostasis.

Platelet receptors have been exploited as therapeutic targets since decades. However, residual platelet reactivity and incidences of bleeding among susceptible individuals often lead to fatal consequences as evident from the outcome of several clinical trials conducted with FDA-approved antiplatelet agents, like P2Y12 antagonists [161] clopidogrel (in CAPRIE, CURE, CREDO, CLARITY, CHARISMA), prasugrel (in TRITON, TRILOGY), ticagrelor (in PLATO and PEGASUS), and competitive inhibitors of PAR-1 against thrombin, i.e., vorapaxar (TRACER [162] and TRA2P [163-165]). Currently, the choice of anti-platelet therapeutics in clinical practice is fairly limited to irreversible COX-1 inhibitor aspirin (ASA) for primary prevention of cardiovascular disease and dual anti-platelet therapy (ASA in combination with reversible (ticagrelor, cangrelor) and irreversible (clopidogrel, prasugrel) inhibitors of P2Y12) for secondary prevention of recurrent thrombotic events following acute coronary syndrome (ACS) or in patients with coronary stent implantation. Clinical trials, like PEGASUS-TIMI54 [166,167], DAPT [168-170], OPTIDUAL [171,172], COMPASS [173-175], and GEMINI-ACS1 [176], reflect their drawbacks in increasing non-fatal/fatal bleeding and falling short of expectations. These trials have validated the potential of single (aspirin), dual and triple anti-platelet therapy or anti-platelet therapy administered in combination with anti-coagulants (rivaroxaban) $[176,177]$. The therapeutic goal is to ascertain the cornerstone of antithrombotic treatment following ACS.

It is essential to prevent recurrent thrombo-ischemic events with efficient thromboprophylactic strategies and reassess the benefit-to-risk ratio [168-172,178,179], dosage regimens, and treatment duration. Novel anti-thrombotic mediators which can discriminate between the physiological processes of thrombosis and hemostasis may potentially achieve this fine balance between anti-thrombotic efficacy and bleeding risk [180]. Of these, specific inhibitors of PI3Kp110 $\beta$ [181] and PKC [182-184], besides tyrosine kinase inhibitors widely recommended against cancer, like SYK, BTK, those of the Src family $[185,186]$, agents antagonizing integrin $\alpha_{\mathrm{IIb}} \beta_{3}$ by specifically targeting the active form of the receptor $[187,188]$ or the outside-in signaling $[189,190]$, a fusion protein combining the extracellular domain of CD39, and a single-chain antibody (Targ-CD39) that specifically detects activated integrin $\alpha_{\text {IIb }} \beta_{3}$ [191] have emerged in recent years. Therapeutics utilizing CD39 [192-194], GPVI [195], and GPIb-IX-V [180] as targets/mediators have been of prime interest. These novel therapeutic targets have been effectively validated in animal models of thrombosis where they were administered before an experimental induction of thrombotic/thrombo-ischemic events, while PI3K $\beta$-inhibitor [196] and soluble GPVI (Revacept ${ }^{\circledR}$ ) are in clinical trials. Some of these strategies like those against tyrosine kinases may exhibit off-target adverse effects on other cells or organs requiring restricted use in limited dose and over a limited time period. The potential anti-thrombotic mediators discussed in this review 
may exert significant influence on thrombotic and thrombo-inflammatory platelet function as these cells interact with the inflamed vascular bed or inflammatory cells, but essentially, these mediators are not prime drivers of platelet function. They may offer a fine-tuning adjustment in modulating important signaling events in platelets to retain physiological hemostasis but check pathological thrombosis. Additionally, potential anti-thrombo-inflammatory benefits of emerging anti-platelet approaches, like those targeting platelet secretion, e.g., inhibitors of platelet lysosome-derived protein disulfide isomerase (PDI) [197,198], recombinant ectonucleases that degrade the platelet agonist ADP [199], platelet-derived soluble P-selectin antagonist as validated in the SELECT-ACS trial [200] and those discussed in this review may be of vital significance in the prevention of thrombo-inflammatory complications associated with ischemic stroke [8], atherosclerosis [201], and other CVDs [202,203] in combating target organ damage following a thrombo-ischemic episode, recurrent thromboembolic events, and in-stent thrombosis. Anti-inflammatory effects of aspirin alone or in combination with P2Y12 antagonists, also rivaroxaban have been seen in clinical settings and in animal models [201]. Most of these beneficial effects stem from reduction in levels of inflammatory mediators like C-reactive protein, IL-6, TNF- $\alpha$, MCP-1, IL- $1 \beta$. The anti-inflammatory benefits of IL- $1 \beta$ targeting monoclonal antibody canakinumab, in the CANTOS-trial [204], in significantly reducing the rate of recurrent cardiovascular events affirm a promising future. Platelets are an active source of thrombo-inflammatory mediators $[82,205]$. The significant association between plasma IL-1 $\beta$ levels and circulatory platelet count, also platelet single-nucleotide polymorphisms (SNPs) assessed in GWAS, while inverse association between platelet count and plasma IL- $1 \beta$ antagonist $\alpha$-1-anti-trypsin, signify the thrombo-inflammatory potential of platelets in CVD [206]. In this light novel therapeutics with additional impact on thrombo-inflammatory processes will certainly have an edge over conventional anti-platelet therapies in clinical practice. However, several important aspects need to be contemplated and verified for a translational implication. The differences in structure and functional response of animal (most often murine) and human platelets, the type and surface availability of receptors, and interspecies differences in the physiological processes of thrombosis-hemostasis are of particular significance. Nevertheless, constant preclinical and clinical research endeavors in delineating the molecular mechanisms dissecting hemostatic and thrombotic or thrombo-inflammatory platelet functions will present more options for therapeutic interventions and broaden the currently limited choice of anti-platelet strategies.

Author Contributions: Conceptualization, M.E.; Writing—original draft preparation, M.C., A.E., L.M.T., L.M.M., M.K., I.K., and M.E.; writing-review and editing, M.K., F.R., I.K., and M.E.; format analysis and figure preparation, F.R.; funding acquisition, M.E. and M.C. All authors have read and agreed to the published version of the manuscript.

Funding: This review was funded by grant from the German Research Foundation (DFG) project number 374031971-TRR 240 (for M.C.), project number 392381697-EL 651/5-1 (for M.E.), project number 236177352-CRC1116 (for M.E.), and International Research Training Group (IRTG) 1902 (project P13 for M.E.).

Conflicts of Interest: The authors declare no conflict of interest.

\section{Abbreviations}

$\begin{array}{ll}\text { AA } & \text { arachidonic acid } \\ \text { ACS } & \text { acute coronary syndrome } \\ \text { ADP } & \text { adenosine diphosphate } \\ \text { ATP } & \text { adenosine triphosphate } \\ \text { ApoER2 } & \text { apolipoprotein E receptor } 2 \\ \text { APP } & \text { amyloid precursor protein } \\ \text { A } \beta & \text { amyloid beta } \\ \text { CAD } & \text { coronary artery diseases } \\ \text { CCR1 }(3,4) & \text { C-C chemokine receptor type } 1(3,4) \\ \text { CLEC } & \text { C-type lectin-like receptor }\end{array}$




\begin{tabular}{|c|c|}
\hline CNS & central nervous system \\
\hline CVD & cardiovascular diseases \\
\hline CXCL11 $(12,16)$ & C-X-C motif chemokine ligand $11(12,16)$ \\
\hline DEP & diesel exhaust particles \\
\hline $\mathrm{DP}_{1}$ & prostaglandin $D_{2}$ receptor 1 \\
\hline DVT & deep vein thrombosis \\
\hline DTS & dense tubular system \\
\hline EC & endothelial cells \\
\hline $\mathrm{EP}_{1-4}$ & prostaglandin $\mathrm{E}_{2}$ receptors $1-4$ \\
\hline Erk & extracellular stimuli-responsive kinase \\
\hline GPCR & G-protein-coupled-receptors \\
\hline GPIb & glycoprotein Ib \\
\hline GPO & glycine-proline-hydroxyproline \\
\hline GPVI & glycoprotein VI \\
\hline IL-6 & interleukin-6 \\
\hline ITAM & immunoreceptor tyrosine-based activation motif \\
\hline LAD & left anterior descending artery \\
\hline LAT & linker for the activation of $\mathrm{T}$ cells \\
\hline MI & myocardial infarction \\
\hline MIF & macrophage migration inhibitory factor \\
\hline MK & megakaryocytes \\
\hline NMDAR & N-methyl-D-aspartate receptor \\
\hline oxLDL & oxidized low density lipoprotein \\
\hline PA & phosphatidic acid \\
\hline PANX1 & pannexin-1 \\
\hline PDI & protein disulfide isomerase \\
\hline $\mathrm{PGD}_{2}$ & prostaglandin $\mathrm{D}_{2}$ \\
\hline $\mathrm{PGE}_{2}$ & prostaglandin $\mathrm{E}_{2}$ \\
\hline $\mathrm{PGI}_{2}$ & prostaglandin $\mathrm{I}_{2}$ \\
\hline PKC & protein kinase $\mathrm{C}$ \\
\hline PLATO & Platelet Inhibition and Patient Outcome \\
\hline PLC $\gamma 2$ & phospholipase $C \gamma 2$ \\
\hline PLD & phospholipase D \\
\hline Prb & probenecid \\
\hline PS & phosphatidylserine \\
\hline SAP & stable angina pectoris \\
\hline SDF-1 & stromal cell-derived factor 1, CXCL12 \\
\hline SFK & Src family kinases \\
\hline SR & scavenger receptor \\
\hline $\mathrm{TP}$ & $\mathrm{TXA}_{2}$ receptor \\
\hline TxA2 & Thromboxane $\mathrm{A}_{2}$ \\
\hline VLDLR & very low density lipoprotein receptor \\
\hline vWF & von Willebrand factor \\
\hline
\end{tabular}

\section{References}

1. GBD 2017 Causes of Death Collaborators. Global, regional, and national age-sex-specific mortality for 282 causes of death in 195 countries and territories, 1980-2017: A systematic analysis for the Global Burden of Disease Study 2017. Lancet 2018, 392, 1736-1788. [CrossRef]

2. GBD 2017 DALYs and HALE Collaborators. Global, regional, and national disability-adjusted life-years (dalys) for 359 diseases and injuries and healthy life expectancy (HALE) for 195 countries and territories, 1990-2017: A systematic analysis for the Global Burden of Disease Study 2017. Lancet 2018, 392, 1859-1922. [CrossRef]

3. Read, S.H.; Wild, S.H. Prevention of premature cardiovascular death worldwide. Lancet 2020, 395, 758-760. [CrossRef] 
4. Gawaz, M. Role of platelets in coronary thrombosis and reperfusion of ischemic myocardium. Cardiovasc. Res. 2004, 61, 498-511. [CrossRef]

5. Ruggeri, Z.M. Platelets in atherothrombosis. Nat. Med. 2002, 8, 1227-1234. [CrossRef]

6. Guo, L.; Rondina, M.T. The era of thromboinflammation: Platelets Are dynamic sensors and effector cells during infectious diseases. Front. Immunol. 2019, 10, 2204. [CrossRef]

7. Schanze, N.; Bode, C.; Duerschmied, D. Platelet Contributions to Myocardial Ischemia/Reperfusion Injury. Front. Immunol. 2019, 10, 1260. [CrossRef]

8. Stoll, G.; Nieswandt, B. Thrombo-inflammation in acute ischaemic stroke-Implications for treatment. Nature reviews. Neurology 2019, 15, 473-481. [CrossRef]

9. Savage, B.; Almus-Jacobs, F.; Ruggeri, Z.M. Specific synergy of multiple substrate-receptor interactions in platelet thrombus formation under flow. Cell 1998, 94, 657-666. [CrossRef]

10. Varga-Szabo, D.; Pleines, I.; Nieswandt, B. Cell adhesion mechanisms in platelets. Arterioscler. Thromb. Vasc. Biol. 2008, 28, 403-412. [CrossRef]

11. Nieswandt, B.; Varga-Szabo, D.; Elvers, M. Integrins in platelet activation. J. Thromb. Haemost. JTH 2009, 7, 206-209. [CrossRef] [PubMed]

12. Jackson, S.P. Arterial thrombosis-Insidious, unpredictable and deadly. Nat. Med. 2011, 17, $1423-1436$. [CrossRef] [PubMed]

13. Asazuma, N.; Ozaki, Y.; Satoh, K.; Yatomi, Y.; Handa, M.; Fujimura, Y.; Miura, S.; Kume, S. Glycoprotein Ib-von Willebrand factor interactions activate tyrosine kinases in human platelets. Blood 1997, 90, 4789-4798. [CrossRef] [PubMed]

14. Falati, S.; Edmead, C.E.; Poole, A.W. Glycoprotein Ib-V-IX, a receptor for von Willebrand factor, couples physically and functionally to the Fc receptor gamma-chain, Fyn, and Lyn to activate human platelets. Blood 1999, 94, 1648-1656. [CrossRef] [PubMed]

15. Ozaki, Y.; Suzuki-Inoue, K.; Inoue, O. Platelet receptors activated via mulitmerization: Glycoprotein VI, GPIb-IX-V, and CLEC-2. J. Thromb. Haemost. JTH 2013, 11, 330-339. [CrossRef]

16. Denorme, F.; De Meyer, S.F. The VWF-GPIb axis in ischaemic stroke: Lessons from animal models. Thromb. Haemost. 2016, 116, 597-604. [CrossRef]

17. Gowert, N.S.; Kruger, I.; Klier, M.; Donner, L.; Kipkeew, F.; Gliem, M.; Bradshaw, N.J.; Lutz, D.; Kober, S.; Langer, H.; et al. Loss of Reelin protects mice against arterial thrombosis by impairing integrin activation and thrombus formation under high shear conditions. Cell. Signal. 2017, 40, 210-221. [CrossRef]

18. Herz, J.; Chen, Y. Reelin, lipoprotein receptors and synaptic plasticity. Nat. Rev. Neurosci. 2006, 7, 850-859. [CrossRef]

19. Leemhuis, J.; Bouche, E.; Frotscher, M.; Henle, F.; Hein, L.; Herz, J.; Meyer, D.K.; Pichler, M.; Roth, G.; Schwan, C.; et al. Reelin signals through apolipoprotein E receptor 2 and Cdc42 to increase growth cone motility and filopodia formation. J. Neurosci. Off. J. Soc. Neurosci. 2010, 30, 14759-14772. [CrossRef]

20. Perez-Costas, E.; Fenton, E.Y.; Caruncho, H.J. Reelin expression in brain endothelial cells: An electron microscopy study. BMC Neurosci. 2015, 16, 16. [CrossRef]

21. Smalheiser, N.R.; Costa, E.; Guidotti, A.; Impagnatiello, F.; Auta, J.; Lacor, P.; Kriho, V.; Pappas, G.D. Expression of reelin in adult mammalian blood, liver, pituitary pars intermedia, and adrenal chromaffin cells. Proc. Natl. Acad. Sci. USA 2000, 97, 1281-1286. [CrossRef] [PubMed]

22. Tseng, W.L.; Huang, C.L.; Chong, K.Y.; Liao, C.H.; Stern, A.; Cheng, J.C.; Tseng, C.P. Reelin is a platelet protein and functions as a positive regulator of platelet spreading on fibrinogen. Cell. Mol. Life Sci. CMLS 2010, 67, 641-653. [CrossRef] [PubMed]

23. Kodaki, T.; Yamashita, S. Cloning, expression, and characterization of a novel phospholipase D complementary DNA from rat brain. J. Biol. Chem. 1997, 272, 11408-11413. [CrossRef] [PubMed]

24. McDermott, M.; Wakelam, M.J.; Morris, A.J. Phospholipase D. Biochem. Cell Biol. 2004, 82, 225-253. [CrossRef]

25. Oude Weernink, P.A.; Lopez de Jesus, M.; Schmidt, M. Phospholipase D signaling: Orchestration by PIP2 and small GTPases. Naunyn Schmiedebergs Arch. Pharmacol. 2007, 374, 399-411. [CrossRef]

26. Elvers, M.; Stegner, D.; Hagedorn, I.; Kleinschnitz, C.; Braun, A.; Kuijpers, M.E.; Boesl, M.; Chen, Q.; Heemskerk, J.W.; Stoll, G.; et al. Impaired alpha(IIb)beta(3) integrin activation and shear-dependent thrombus formation in mice lacking phospholipase D1. Sci. Signal. 2010, 3, ra1. [CrossRef] 
27. Thielmann, I.; Stegner, D.; Kraft, P.; Hagedorn, I.; Krohne, G.; Kleinschnitz, C.; Stoll, G.; Nieswandt, B. Redundant functions of phospholipases D1 and D2 in platelet alpha-granule release. J. Thromb. Haemost. JTH 2012, 10, 2361-2372. [CrossRef]

28. Klose, A.M.; Klier, M.; Gorressen, S.; Elvers, M. Enhanced Integrin Activation of PLD2-Deficient Platelets Accelerates Inflammation after Myocardial Infarction. Int. J. Mol. Sci. 2020, 21. [CrossRef]

29. Klier, M.; Gowert, N.S.; Jackel, S.; Reinhardt, C.; Elvers, M. Phospholipase D1 is a regulator of platelet-mediated inflammation. Cell. Signal. 2017, 38, 171-181. [CrossRef]

30. Simon, D.I.; Chen, Z.; Xu, H.; Li, C.Q.; Dong, J.; McIntire, L.V.; Ballantyne, C.M.; Zhang, L.; Furman, M.I.; Berndt, M.C.; et al. Platelet glycoprotein ibalpha is a counterreceptor for the leukocyte integrin Mac-1 (CD11b/CD18). J. Exp. Med. 2000, 192, 193-204. [CrossRef]

31. Schönberger, T.; Jürgens, T.; Müller, J.; Armbruster, N.; Niermann, C.; Gorressen, S.; Sommer, J.; Tian, H.; di Paolo, G.; Scheller, J.; et al. Pivotal role of phospholipase D1 in tumor necrosis factor- $\alpha$-mediated inflammation and scar formation after myocardial ischemia and reperfusion in mice. Am. J. Pathol. 2014, 184, 2450-2464. [CrossRef]

32. Bender, M.; May, F.; Lorenz, V.; Thielmann, I.; Hagedorn, I.; Finney, B.A.; Vogtle, T.; Remer, K.; Braun, A.; Bosl, M.; et al. Combined in vivo depletion of glycoprotein VI and C-type lectin-like receptor 2 severely compromises hemostasis and abrogates arterial thrombosis in mice. Arterioscler. Thromb. Vasc. Biol. 2013, 33, 926-934. [CrossRef]

33. Dumont, B.; Lasne, D.; Rothschild, C.; Bouabdelli, M.; Ollivier, V.; Oudin, C.; Ajzenberg, N.; Grandchamp, B.; Jandrot-Perrus, M. Absence of collagen-induced platelet activation caused by compound heterozygous GPVI mutations. Blood 2009, 114, 1900-1903. [CrossRef] [PubMed]

34. Moroi, M.; Jung, S.M.; Okuma, M.; Shinmyozu, K. A patient with platelets deficient in glycoprotein VI that lack both collagen-induced aggregation and adhesion. J. Clin. Investig. 1989, 84, 1440-1445. [CrossRef] [PubMed]

35. Bergmeier, W.; Stefanini, L. Platelet ITAM signaling. Curr. Opin. Hematol. 2013, 20, 445-450. [CrossRef] [PubMed]

36. Boulaftali, Y.; Hess, P.R.; Getz, T.M.; Cholka, A.; Stolla, M.; Mackman, N.; Owens, A.P., III; Ware, J.; Kahn, M.L.; Bergmeier, W. Platelet ITAM signaling is critical for vascular integrity in inflammation. J. Clin. Investig. 2013, 123, 908-916. [CrossRef]

37. Rayes, J.; Watson, S.P.; Nieswandt, B. Functional significance of the platelet immune receptors GPVI and CLEC-2. J. Clin. Investig. 2019, 129, 12-23. [CrossRef]

38. Miura, Y.; Takahashi, T.; Jung, S.M.; Moroi, M. Analysis of the interaction of platelet collagen receptor glycoprotein VI (GPVI) with collagen. A dimeric form of GPVI, but not the monomeric form, shows affinity to fibrous collagen. J. Biol. Chem. 2002, 277, 46197-46204. [CrossRef]

39. Alshehri, O.M.; Hughes, C.E.; Montague, S.; Watson, S.K.; Frampton, J.; Bender, M.; Watson, S.P. Fibrin activates GPVI in human and mouse platelets. Blood 2015, 126, 1601-1608. [CrossRef]

40. Alshehri, O.M.; Montague, S.; Watson, S.; Carter, P.; Sarker, N.; Manne, B.K.; Miller, J.L.; Herr, A.B.; Pollitt, A.Y.; O'Callaghan, C.A.; et al. Activation of glycoprotein VI (GPVI) and C-type lectin-like receptor-2 (CLEC-2) underlies platelet activation by diesel exhaust particles and other charged/hydrophobic ligands. Biochem. J. 2015, 468, 459-473. [CrossRef]

41. Onselaer, M.B.; Hardy, A.T.; Wilson, C.; Sanchez, X.; Babar, A.K.; Miller, J.L.C.; Watson, C.N.; Watson, S.K.; Bonna, A.; Philippou, H.; et al. Fibrin and D-dimer bind to monomeric GPVI. Blood Adv. 2017, 1, 1495-1504. [CrossRef]

42. Mammadova-Bach, E.; Ollivier, V.; Loyau, S.; Schaff, M.; Dumont, B.; Favier, R.; Freyburger, G.; Latger-Cannard, V.; Nieswandt, B.; Gachet, C.; et al. Platelet glycoprotein VI binds to polymerized fibrin and promotes thrombin generation. Blood 2015, 126, 683-691. [CrossRef]

43. Bigalke, B.; Elvers, M.; Schönberger, T.; Gawaz, M. Platelet and soluble glycoprotein VI-novel applications in diagnosis and therapy. Curr. Drug Targets 2011, 12, 1821-1830. [CrossRef] [PubMed]

44. Bigalke, B.; Lindemann, S.; Ehlers, R.; Seizer, P.; Daub, K.; Langer, H.; Schonberger, T.; Kremmer, E.; Siegel-Axel, D.; May, A.E.; et al. Expression of platelet collagen receptor glycoprotein VI is associated with acute coronary syndrome. Eur. Heart J. 2006, 27, 2165-2169. [CrossRef]

45. Chatterjee, M.; Gawaz, M. Clinical significance of receptor shedding-platelet GPVI as an emerging diagnostic and therapeutic tool. Platelets 2017, 28, 362-371. [CrossRef] 
46. Ollikainen, E.; Mikkelsson, J.; Perola, M.; Penttilä, A.; Karhunen, P.J. Platelet membrane collagen receptor glycoprotein VI polymorphism is associated with coronary thrombosis and fatal myocardial infarction in middle-aged men. Atherosclerosis 2004, 176, 95-99. [CrossRef] [PubMed]

47. Samaha, F.F.; Hibbard, C.; Sacks, J.; Chen, H.; Varello, M.A.; George, T.; Kahn, M.L. Density of platelet collagen receptors glycoprotein VI and alpha2beta1 and prior myocardial infarction in human subjects, a pilot study. Med. Sci. Monit. 2005, 11, Cr224-Cr229.

48. Gawaz, M.; Konrad, I.; Hauser, A.I.; Sauer, S.; Li, Z.; Wester, H.J.; Bengel, F.M.; Schwaiger, M.; Schömig, A.; Massberg, S.; et al. Non-invasive imaging of glycoprotein VI binding to injured arterial lesions. Thromb. Haemost. 2005, 93, 910-913. [CrossRef] [PubMed]

49. Goebel, S.; Li, Z.; Vogelmann, J.; Holthoff, H.P.; Degen, H.; Hermann, D.M.; Gawaz, M.; Ungerer, M.; Münch, G. The GPVI-Fc fusion protein Revacept improves cerebral infarct volume and functional outcome in stroke. PLoS ONE 2013, 8, e66960. [CrossRef] [PubMed]

50. Gruner, S.; Prostredna, M.; Koch, M.; Miura, Y.; Schulte, V.; Jung, S.M.; Moroi, M.; Nieswandt, B. Relative antithrombotic effect of soluble GPVI dimer compared with anti-GPVI antibodies in mice. Blood 2005, 105, 1492-1499. [CrossRef]

51. Jamasbi, J.; Megens, R.T.; Bianchini, M.; Münch, G.; Ungerer, M.; Faussner, A.; Sherman, S.; Walker, A.; Goyal, P.; Jung, S.; et al. Differential Inhibition of Human Atherosclerotic Plaque-Induced Platelet Activation by Dimeric GPVI-Fc and Anti-GPVI Antibodies: Functional and Imaging Studies. J. Am. Coll. Cardiol. 2015, 65, 2404-2415. [CrossRef]

52. Massberg, S.; Konrad, I.; Bültmann, A.; Schulz, C.; Münch, G.; Peluso, M.; Lorenz, M.; Schneider, S.; Besta, F.; Müller, I.; et al. Soluble glycoprotein VI dimer inhibits platelet adhesion and aggregation to the injured vessel wall in vivo. FASEB J. 2004, 18, 397-399. [CrossRef]

53. Schulz, C.; Penz, S.; Hoffmann, C.; Langer, H.; Gillitzer, A.; Schneider, S.; Brandl, R.; Seidl, S.; Massberg, S.; Pichler, B.; et al. Platelet GPVI binds to collagenous structures in the core region of human atheromatous plaque and is critical for atheroprogression in vivo. Basic Res. Cardiol. 2008, 103, 356-367. [CrossRef]

54. Ungerer, M.; Li, Z.; Baumgartner, C.; Goebel, S.; Vogelmann, J.; Holthoff, H.P.; Gawaz, M.; Münch, G. The GPVI-Fc fusion protein Revacept reduces thrombus formation and improves vascular dysfunction in atherosclerosis without any impact on bleeding times. PLoS ONE 2013, 8, e71193. [CrossRef]

55. Schönberger, T.; Ziegler, M.; Borst, O.; Konrad, I.; Nieswandt, B.; Massberg, S.; Ochmann, C.; Jürgens, T.; Seizer, P.; Langer, H.; et al. The dimeric platelet collagen receptor GPVI-Fc reduces platelet adhesion to activated endothelium and preserves myocardial function after transient ischemia in mice. Am. J. Physiol. Cell Physiol. 2012, 303, C757-C766. [CrossRef]

56. Ziegler, M.; Elvers, M.; Baumer, Y.; Leder, C.; Ochmann, C.; Schonberger, T.; Jurgens, T.; Geisler, T.; Schlosshauer, B.; Lunov, O.; et al. The bispecific SDF1-GPVI fusion protein preserves myocardial function after transient ischemia in mice. Circulation 2012, 125, 685-696. [CrossRef] [PubMed]

57. Krueger, I.; Gremer, L.; Mangels, L.; Klier, M.; Jurk, K.; Willbold, D.; Bock, H.H.; Elvers, M. Reelin amplifies GPVI activation and alphaiib beta3 integrin outside-in signaling via PLC gamma 2 and Rho GTPases. Arterioscler. Thromb. Vasc. Biol. 2020. [CrossRef]

58. Severin, S.; Pollitt, A.Y.; Navarro-Nunez, L.; Nash, C.A.; Mourao-Sa, D.; Eble, J.A.; Senis, Y.A.; Watson, S.P. Syk-dependent phosphorylation of CLEC-2: A novel mechanism of hem-immunoreceptor tyrosine-based activation motif signaling. J. Biol. Chem. 2011, 286, 4107-4116. [CrossRef] [PubMed]

59. Manne, B.K.; Badolia, R.; Dangelmaier, C.; Eble, J.A.; Ellmeier, W.; Kahn, M.; Kunapuli, S.P. Distinct pathways regulate Syk protein activation downstream of immune tyrosine activation motif (ITAM) and hemITAM receptors in platelets. J. Biol. Chem. 2015, 290, 11557-11568. [CrossRef]

60. Hughes, C.E.; Navarro-Nunez, L.; Finney, B.A.; Mourao-Sa, D.; Pollitt, A.Y.; Watson, S.P. CLEC-2 is not required for platelet aggregation at arteriolar shear. J. Thromb. Haemost. JTH 2010, 8, 2328-2332. [CrossRef]

61. May, F.; Hagedorn, I.; Pleines, I.; Bender, M.; Vögtle, T.; Eble, J.; Elvers, M.; Nieswandt, B. CLEC-2 is an essential platelet-activating receptor in hemostasis and thrombosis. Blood 2009, 114, 3464-3472. [CrossRef] [PubMed]

62. Kleinschnitz, C.; Pozgajova, M.; Pham, M.; Bendszus, M.; Nieswandt, B.; Stoll, G. Targeting platelets in acute experimental stroke: Impact of glycoprotein $\mathrm{Ib}, \mathrm{VI}$, and IIb/IIIa blockade on infarct size, functional outcome, and intracranial bleeding. Circulation 2007, 115, 2323-2330. [CrossRef] [PubMed] 
63. Pachel, C.; Mathes, D.; Arias-Loza, A.P.; Heitzmann, W.; Nordbeck, P.; Deppermann, C.; Lorenz, V.; Hofmann, U.; Nieswandt, B.; Frantz, S. Inhibition of Platelet GPVI Protects Against Myocardial Ischemia-Reperfusion Injury. Arterioscler. Thromb. Vasc. Biol. 2016, 36, 629-635. [CrossRef] [PubMed]

64. Donner, L.; Toska, L.M.; Kruger, I.; Groniger, S.; Barroso, R.; Burleigh, A.; Mezzano, D.; Pfeiler, S.; Kelm, M.; Gerdes, N.; et al. The collagen receptor glycoprotein VI promotes platelet-mediated aggregation of beta-amyloid. Sci. Signal. 2020, 13. [CrossRef] [PubMed]

65. Payne, H.; Ponomaryov, T.; Watson, S.P.; Brill, A. Mice with a deficiency in CLEC-2 are protected against deep vein thrombosis. Blood 2017, 129, 2013-2020. [CrossRef]

66. Nicolson, P.L.; Welsh, J.D.; Chauhan, A.; Thomas, M.R.; Kahn, M.L.; Watson, S.P. A rationale for blocking thromboinflammation in COVID-19 with Btk inhibitors. Platelets 2020, 31, 685-690. [CrossRef]

67. Yeung, J.; Li, W.; Holinstat, M. Platelet Signaling and Disease: Targeted Therapy for Thrombosis and Other Related Diseases. Pharmacol. Rev. 2018, 70, 526-548. [CrossRef]

68. Moers, A.; Nieswandt, B.; Massberg, S.; Wettschureck, N.; Gruner, S.; Konrad, I.; Schulte, V.; Aktas, B.; Gratacap, M.P.; Simon, M.I.; et al. G13 is an essential mediator of platelet activation in hemostasis and thrombosis. Nat. Med. 2003, 9, 1418-1422. [CrossRef]

69. Woulfe, D.S. Platelet G protein-coupled receptors in hemostasis and thrombosis. J. Thromb. Haemost. JTH 2005, 3, 2193-2200. [CrossRef]

70. Wong, S.K.; Parker, E.M.; Ross, E.M. Chimeric muscarinic cholinergic: Beta-adrenergic receptors that activate Gs in response to muscarinic agonists. J. Biol. Chem. 1990, 265, 6219-6224.

71. Kroeze, W.K.; Sheffler, D.J.; Roth, B.L. G-protein-coupled receptors at a glance. J. Cell Sci. 2003, 116, 4867-4869. [CrossRef] [PubMed]

72. Cheng, Y.; Austin, S.C.; Rocca, B.; Koller, B.H.; Coffman, T.M.; Grosser, T.; Lawson, J.A.; FitzGerald, G.A. Role of prostacyclin in the cardiovascular response to thromboxane A2. Science 2002, 296, 539-541. [CrossRef] [PubMed]

73. van der Meijden, P.E.J.; Heemskerk, J.W.M. Platelet biology and functions: New concepts and clinical perspectives. Nat. Rev. Cardiol. 2019, 16, 166-179. [CrossRef] [PubMed]

74. Fender, A.C.; Rauch, B.H.; Geisler, T.; Schror, K. Protease-Activated Receptor PAR-4: An Inducible Switch between Thrombosis and Vascular Inflammation? Thromb. Haemost. 2017, 117, 2013-2025. [CrossRef] [PubMed]

75. Quinton, T.M.; Murugappan, S.; Kim, S.; Jin, J.; Kunapuli, S.P. Different G protein-coupled signaling pathways are involved in alpha granule release from human platelets. J. Thromb. Haemost. JTH 2004, 2, 978-984. [CrossRef] [PubMed]

76. Quinton, T.M.; Kim, S.; Jin, J.; Kunapuli, S.P. Lipid rafts are required in Galpha(i) signaling downstream of the P2Y12 receptor during ADP-mediated platelet activation. J. Thromb. Haemost. JTH 2005, 3, 1036-1041. [CrossRef] [PubMed]

77. Nieman, M.T. Protease-activated receptors in hemostasis. Blood 2016, 128, 169-177. [CrossRef]

78. Holinstat, M.; Boutaud, O.; Apopa, P.L.; Vesci, J.; Bala, M.; Oates, J.A.; Hamm, H.E. Protease-activated receptor signaling in platelets activates cytosolic phospholipase A2alpha differently for cyclooxygenase-1 and 12-lipoxygenase catalysis. Arterioscler. Thromb. Vasc. Biol. 2011, 31, 435-442. [CrossRef]

79. Franchi, F.; Rollini, F.; Angiolillo, D.J. Antithrombotic therapy for patients with STEMI undergoing primary PCI. Nat. Rev. Cardiol. 2017, 14, 361-379. [CrossRef]

80. Kovacs, I.B.; Mayou, S.C.; Kirby, J.D. Infusion of a stable prostacyclin analogue, iloprost, to patients with peripheral vascular disease: Lack of antiplatelet effect but risk of thromboembolism. Am. J. Med. 1991, 90, 41-46. [CrossRef]

81. Gleissner, C.A.; von Hundelshausen, P.; Ley, K. Platelet chemokines in vascular disease. Arterioscler. Thromb. Vasc. Biol. 2008, 28, 1920-1927. [CrossRef] [PubMed]

82. Chatterjee, M.; Geisler, T. Inflammatory Contribution of Platelets Revisited: New Players in the Arena of Inflammation. Semin. Thromb. Hemost. 2016, 42, 205-214. [CrossRef] [PubMed]

83. Gear, A.R.; Camerini, D. Platelet chemokines and chemokine receptors: Linking hemostasis, inflammation, and host defense. Microcirculation 2003, 10, 335-350. [CrossRef] [PubMed]

84. Bakogiannis, C.; Sachse, M.; Stamatelopoulos, K.; Stellos, K. Platelet-derived chemokines in inflammation and atherosclerosis. Cytokine 2019, 122, 154157. [CrossRef] [PubMed] 
85. Clemetson, K.J.; Clemetson, J.M.; Proudfoot, A.E.; Power, C.A.; Baggiolini, M.; Wells, T.N. Functional expression of CCR1, CCR3, CCR4, and CXCR4 chemokine receptors on human platelets. Blood 2000, 96, 4046-4054. [CrossRef] [PubMed]

86. Rath, D.; Chatterjee, M.; Borst, O.; Muller, K.; Langer, H.; Mack, A.F.; Schwab, M.; Winter, S.; Gawaz, M.; Geisler, T. Platelet surface expression of stromal cell-derived factor-1 receptors CXCR4 and CXCR7 is associated with clinical outcomes in patients with coronary artery disease. J. Thromb. Haemost. JTH 2015, 13, 719-728. [CrossRef]

87. Rath, D.; Chatterjee, M.; Borst, O.; Muller, K.; Stellos, K.; Mack, A.F.; Bongartz, A.; Bigalke, B.; Langer, H.; Schwab, M.; et al. Expression of stromal cell-derived factor-1 receptors CXCR4 and CXCR7 on circulating platelets of patients with acute coronary syndrome and association with left ventricular functional recovery. Eur. Heart. J. 2014, 35, 386-394. [CrossRef]

88. Borst, O.; Munzer, P.; Gatidis, S.; Schmidt, E.M.; Schonberger, T.; Schmid, E.; Towhid, S.T.; Stellos, K.; Seizer, P.; May, A.E.; et al. The inflammatory chemokine CXC motif ligand 16 triggers platelet activation and adhesion via CXC motif receptor 6-dependent phosphatidylinositide 3-kinase/Akt signaling. Circ. Res. 2012, 111, 1297-1307. [CrossRef]

89. Massberg, S.; Konrad, I.; Schurzinger, K.; Lorenz, M.; Schneider, S.; Zohlnhoefer, D.; Hoppe, K.; Schiemann, M.; Kennerknecht, E.; Sauer, S.; et al. Platelets secrete stromal cell-derived factor 1alpha and recruit bone marrow-derived progenitor cells to arterial thrombi in vivo. J. Exp. Med. 2006, 203, 1221-1233. [CrossRef]

90. Chatterjee, M.; Gawaz, M. Platelet-derived CXCL12 (SDF-1alpha): Basic mechanisms and clinical implications. J. Thromb. Haemost. JTH 2013, 11, 1954-1967. [CrossRef]

91. Wirtz, T.H.; Tillmann, S.; Strussmann, T.; Kraemer, S.; Heemskerk, J.W.; Grottke, O.; Gawaz, M.; von Hundelshausen, P.; Bernhagen, J. Platelet-derived MIF: A novel platelet chemokine with distinct recruitment properties. Atherosclerosis 2015, 239, 1-10. [CrossRef] [PubMed]

92. Strussmann, T.; Tillmann, S.; Wirtz, T.; Bucala, R.; von Hundelshausen, P.; Bernhagen, J. Platelets are a previously unrecognised source of MIF. Thromb. Haemost. 2013, 110, 1004-1013. [CrossRef] [PubMed]

93. Chatterjee, M.; von Ungern-Sternberg, S.N.; Seizer, P.; Schlegel, F.; Buttcher, M.; Sindhu, N.A.; Muller, S.; Mack, A.; Gawaz, M. Platelet-derived CXCL12 regulates monocyte function, survival, differentiation into macrophages and foam cells through differential involvement of CXCR4-CXCR7. Cell Death. Dis. 2015, 6, e1989. [CrossRef] [PubMed]

94. Sun, Y.; Chang, Z.; Zhang, S. Increased serum CXCL16 level is a marker for acute coronary syndromes. Arch. Med. Res. 2008, 39, 332-337. [CrossRef]

95. Lehrke, M.; Millington, S.C.; Lefterova, M.; Cumaranatunge, R.G.; Szapary, P.; Wilensky, R.; Rader, D.J.; Lazar, M.A.; Reilly, M.P. CXCL16 is a marker of inflammation, atherosclerosis, and acute coronary syndromes in humans. J. Am. Coll. Cardiol. 2007, 49, 442-449. [CrossRef]

96. Jansson, A.M.; Aukrust, P.; Ueland, T.; Smith, C.; Omland, T.; Hartford, M.; Caidahl, K. Soluble CXCL16 predicts long-term mortality in acute coronary syndromes. Circulation 2009, 119, 3181-3188. [CrossRef]

97. Tan, K.; Lu, S.; Chen, Y.; Song, X.; Wu, X.; Jin, Z.; Yuan, F.; Zhou, Y.; Li, H.; Yang, T.; et al. CXC chemokine ligand 16 as a prognostic marker in patients with intermediate coronary artery lesions: A 2-year follow-up study. Tohoku J. Exp. Med. 2011, 223, 277-283. [CrossRef]

98. Andersen, T.; Ueland, T.; Ghukasyan Lakic, T.; Åkerblom, A.; Bertilsson, M.; Aukrust, P.; Michelsen, A.E.; James, S.K.; Becker, R.C.; Storey, R.F.; et al. C-X-C Ligand 16 Is an Independent Predictor of Cardiovascular Death and Morbidity in Acute Coronary Syndromes. Arterioscler. Thromb. Vasc. Biol. 2019, 39, $2402-2410$. [CrossRef]

99. Seizer, P.; Stellos, K.; Selhorst, G.; Kramer, B.F.; Lang, M.R.; Gawaz, M.; May, A.E. CXCL16 is a novel scavenger receptor on platelets and is associated with acute coronary syndrome. Thromb. Haemost. 2011, 105, 1112-1114. [CrossRef]

100. Meyer Dos Santos, S.; Blankenbach, K.; Scholich, K.; Dorr, A.; Monsefi, N.; Keese, M.; Linke, B.; Deckmyn, H.; Nelson, K.; Harder, S. Platelets from flowing blood attach to the inflammatory chemokine CXCL16 expressed in the endothelium of the human vessel wall. Thromb. Haemost. 2015, 114, 297-312. [CrossRef]

101. Chatterjee, M.; Borst, O.; Walker, B.; Fotinos, A.; Vogel, S.; Seizer, P.; Mack, A.; Alampour-Rajabi, S.; Rath, D.; Geisler, T.; et al. Macrophage migration inhibitory factor limits activation-induced apoptosis of platelets via CXCR7-dependent Akt signaling. Circ. Res. 2014, 115, 939-949. [CrossRef] 
102. Chatterjee, M.; Seizer, P.; Borst, O.; Schonberger, T.; Mack, A.; Geisler, T.; Langer, H.F.; May, A.E.; Vogel, S.; Lang, F.; et al. SDF-1alpha induces differential trafficking of CXCR4-CXCR7 involving cyclophilin A, CXCR7 ubiquitination and promotes platelet survival. FASEB J. 2014, 28, 2864-2878. [CrossRef] [PubMed]

103. Rath, D.; Chatterjee, M.; Meyer, L.; Tekath, N.; Olma, C.; Krumm, P.; Adams, C.; Borst, O.; Muller, K.; Droppa, M.; et al. Relative survival potential of platelets is associated with platelet CXCR4/CXCR7 surface exposure and functional recovery following STEMI. Atherosclerosis 2018, 278, 269-277. [CrossRef]

104. Kraemer, B.F.; Schmidt, C.; Urban, B.; Bigalke, B.; Schwanitz, L.; Koch, M.; Seizer, P.; Schaller, M.; Gawaz, M.; Lindemann, S. High shear flow induces migration of adherent human platelets. Platelets 2011, 22, 415-421. [CrossRef]

105. Kraemer, B.F.; Borst, O.; Gehring, E.M.; Schoenberger, T.; Urban, B.; Ninci, E.; Seizer, P.; Schmidt, C.; Bigalke, B.; Koch, M.; et al. PI3 kinase-dependent stimulation of platelet migration by stromal cell-derived factor 1 (SDF-1). J. Mol. Med. (Berl.) 2010, 88, 1277-1288. [CrossRef]

106. Kowalska, M.A.; Ratajczak, M.Z.; Majka, M.; Jin, J.; Kunapuli, S.; Brass, L.; Poncz, M. Stromal cell-derived factor-1 and macrophage-derived chemokine: 2 chemokines that activate platelets. Blood 2000, 96, 50-57. [CrossRef]

107. Abi-Younes, S.; Sauty, A.; Mach, F.; Sukhova, G.K.; Libby, P.; Luster, A.D. The stromal cell-derived factor-1 chemokine is a potent platelet agonist highly expressed in atherosclerotic plaques. Circ. Res. 2000, 86, 131-138. [CrossRef]

108. Gear, A.R.; Suttitanamongkol, S.; Viisoreanu, D.; Polanowska-Grabowska, R.K.; Raha, S.; Camerini, D. Adenosine diphosphate strongly potentiates the ability of the chemokines MDC, TARC, and SDF-1 to stimulate platelet function. Blood 2001, 97, 937-945. [CrossRef]

109. Walsh, T.G.; Harper, M.T.; Poole, A.W. SDF-1alpha is a novel autocrine activator of platelets operating through its receptor CXCR4. Cell. Signal. 2015, 27, 37-46. [CrossRef]

110. Ohtsuka, H.; Iguchi, T.; Hayashi, M.; Kaneda, M.; Iida, K.; Shimonaka, M.; Hara, T.; Arai, M.; Koike, Y.; Yamamoto, N.; et al. SDF-1alpha/CXCR4 Signaling in Lipid Rafts Induces Platelet Aggregation via PI3 Kinase-Dependent Akt Phosphorylation. PLoS ONE 2017, 12, e0169609. [CrossRef]

111. Salim, J.P.; Goette, N.P.; Lev, P.R.; Chazarreta, C.D.; Heller, P.G.; Alvarez, C.; Molinas, F.C.; Marta, R.F. Dysregulation of stromal derived factor $1 / \mathrm{CXCR} 4$ axis in the megakaryocytic lineage in essential thrombocythemia. Br. J. Haematol. 2009, 144, 69-77. [CrossRef] [PubMed]

112. Chatterjee, M.; Rath, D.; Schlotterbeck, J.; Rheinlaender, J.; Walker-Allgaier, B.; Alnaggar, N.; Zdanyte, M.; Muller, I.; Borst, O.; Geisler, T.; et al. Regulation of oxidized platelet lipidome: Implications for coronary artery disease. Eur. Heart. J. 2017, 38, 1993-2005. [CrossRef] [PubMed]

113. Stellos, K.; Ruf, M.; Sopova, K.; Kilias, A.; Rahmann, A.; Stamatelopoulos, K.; Jorbenadze, R.; Geisler, T.; Gawaz, M.; Bigalke, B. Plasma levels of stromal cell-derived factor-1 in patients with coronary artery disease: Effect of clinical presentation and cardiovascular risk factors. Atherosclerosis 2011, 219, 913-916. [CrossRef] [PubMed]

114. Müller, I.I.; Müller, K.A.; Schönleber, H.; Karathanos, A.; Schneider, M.; Jorbenadze, R.; Bigalke, B.; Gawaz, M.; Geisler, T. Macrophage migration inhibitory factor is enhanced in acute coronary syndromes and is associated with the inflammatory response. PLoS ONE 2012, 7, e38376. [CrossRef] [PubMed]

115. Hynes, R.O. Integrins: Bidirectional, allosteric signaling machines. Cell 2002, 110, 673-687. [CrossRef]

116. Jennings, L.K.; Phillips, D.R. Purification of glycoproteins Ilb and III from human platelet plasma membranes and characterization of a calcium-dependent glycoprotein Ilb-III complex. J. Biol. Chem. 1982, 257, 10458-10466.

117. Hynes, R.O. Integrins: Versatility, modulation, and signaling in cell adhesion. Cell 1992, 69, 11-25. [CrossRef]

118. Lefkovits, J.; Plow, E.F.; Topol, E.J. Platelet glycoprotein IIb/IIIa receptors in cardiovascular medicine. N. Engl. J. Med. 1995, 332, 1553-1559. [CrossRef]

119. Hynes, R.O. Integrins: A family of cell surface receptors. Cell 1987, 48, 549-554. [CrossRef]

120. Wagner, C.L.; Mascelli, M.A.; Neblock, D.S.; Weisman, H.F.; Coller, B.S.; Jordan, R.E. Analysis of GPIIb/IIIa receptor number by quantification of 7E3 binding to human platelets. Blood 1996, 88, 907-914. [CrossRef]

121. Wencel-Drake, J.D.; Plow, E.F.; Kunicki, T.J.; Woods, V.L.; Keller, D.M.; Ginsberg, M.H. Localization of internal pools of membrane glycoproteins involved in platelet adhesive responses. Am. J. Pathol. 1986, 124, 324-334.

122. Favier, M.; Bordet, J.C.; Favier, R.; Gkalea, V.; Pillois, X.; Rameau, P.; Debili, N.; Alessi, M.C.; Nurden, P.; Raslova, H.; et al. Mutations of the integrin $\alpha \mathrm{Ilb} / \beta 3$ intracytoplasmic salt bridge cause macrothrombocytopenia and enlarged platelet $\alpha$-granules. Am. J. Hematol. 2018, 93, 195-204. [CrossRef] 
123. Nieswandt, B.; Moser, M.; Pleines, I.; Varga-Szabo, D.; Monkley, S.; Critchley, D.; Fassler, R. Loss of talin1 in platelets abrogates integrin activation, platelet aggregation, and thrombus formation in vitro and in vivo. J. Exp. Med. 2007, 204, 3113-3118. [CrossRef] [PubMed]

124. Moser, M.; Nieswandt, B.; Ussar, S.; Pozgajova, M.; Fassler, R. Kindlin-3 is essential for integrin activation and platelet aggregation. Nat. Med. 2008, 14, 325-330. [CrossRef] [PubMed]

125. Estevez, B.; Shen, B.; Du, X. Targeting integrin and integrin signaling in treating thrombosis. Arterioscler. Thromb. Vasc. Biol. 2015, 35, 24-29. [CrossRef] [PubMed]

126. Gao, J.; Huang, M.; Lai, J.; Mao, K.; Sun, P.; Cao, Z.; Hu, Y.; Zhang, Y.; Schulte, M.L.; Jin, C.; et al. Kindlin supports platelet integrin alphaIlbbeta3 activation by interacting with paxillin. J. Cell Sci. 2017, 130, 3764-3775. [CrossRef]

127. Huang, J.; Li, X.; Shi, X.; Zhu, M.; Wang, J.; Huang, S.; Huang, X.; Wang, H.; Li, L.; Deng, H.; et al. Platelet integrin $\alpha \mathrm{Ilb} \beta 3$ : Signal transduction, regulation, and its therapeutic targeting. J. Hematol. Oncol. 2019, 12, 26. [CrossRef]

128. Lahav, J.; Gofer-Dadosh, N.; Luboshitz, J.; Hess, O.; Shaklai, M. Protein disulfide isomerase mediates integrin-dependent adhesion. FEBS Lett. 2000, 475, 89-92. [CrossRef]

129. Lahav, J.; Jurk, K.; Hess, O.; Barnes, M.J.; Farndale, R.W.; Luboshitz, J.; Kehrel, B.E. Sustained integrin ligation involves extracellular free sulfhydryls and enzymatically catalyzed disulfide exchange. Blood 2002, 100, 2472-2478. [CrossRef]

130. Jasuja, R.; Passam, F.H.; Kennedy, D.R.; Kim, S.H.; van Hessem, L.; Lin, L.; Bowley, S.R.; Joshi, S.S.; Dilks, J.R.; Furie, B.; et al. Protein disulfide isomerase inhibitors constitute a new class of antithrombotic agents. J. Clin. Investig. 2012, 122, 2104-2113. [CrossRef]

131. Zwicker, J.I.; Schlechter, B.L.; Stopa, J.D.; Liebman, H.A.; Aggarwal, A.; Puligandla, M.; Caughey, T.; Bauer, K.A.; Kuemmerle, N.; Wong, E.; et al. Targeting protein disulfide isomerase with the flavonoid isoquercetin to improve hypercoagulability in advanced cancer. JCI Insight 2019, 4. [CrossRef] [PubMed]

132. Wu, Y.; Span, L.M.; Nygren, P.; Zhu, H.; Moore, D.T.; Cheng, H.; Roder, H.; DeGrado, W.F.; Bennett, J.S. The Tyrosine Kinase c-Src Specifically Binds to the Active Integrin $\alpha \mathrm{IIb} \beta 3$ to Initiate Outside-in Signaling in Platelets. J. Biol. Chem. 2015, 290, 15825-15834. [CrossRef]

133. Obergfell, A.; Eto, K.; Mocsai, A.; Buensuceso, C.; Moores, S.L.; Brugge, J.S.; Lowell, C.A.; Shattil, S.J. Coordinate interactions of Csk, Src, and Syk kinases with [alpha]IIb[beta]3 initiate integrin signaling to the cytoskeleton. J. Cell Biol. 2002, 157, 265-275. [CrossRef] [PubMed]

134. Suzuki-Inoue, K.; Hughes, C.E.; Inoue, O.; Kaneko, M.; Cuyun-Lira, O.; Takafuta, T.; Watson, S.P.; Ozaki, Y. Involvement of Src kinases and PLCgamma2 in clot retraction. Thromb. Res. 2007, 120, 251-258. [CrossRef] [PubMed]

135. Elvers, M.; Pozgaj, R.; Pleines, I.; May, F.; Kuijpers, M.J.; Heemskerk, J.M.; Yu, P.; Nieswandt, B. Platelet hyperreactivity and a prothrombotic phenotype in mice with a gain-of-function mutation in phospholipase Cgamma2. J. Thromb. Haemost. JTH 2010, 8, 1353-1363. [CrossRef]

136. Bye, A.P.; Unsworth, A.J.; Vaiyapuri, S.; Stainer, A.R.; Fry, M.J.; Gibbins, J.M. Ibrutinib Inhibits Platelet Integrin alphaIIbbeta3 Outside-In Signaling and Thrombus Stability but Not Adhesion to Collagen. Arterioscler. Thromb. Vasc. Biol. 2015, 35, 2326-2335. [CrossRef]

137. Dobie, G.; Kuriri, F.A.; Omar, M.M.A.; Alanazi, F.; Gazwani, A.M.; Tang, C.P.S.; Sze, D.M.; Handunnetti, S.M.; Tam, C.; Jackson, D.E. Ibrutinib, but not zanubrutinib, induces platelet receptor shedding of GPIb-IX-V complex and integrin alphaIlbbeta3 in mice and humans. Blood Adv. 2019, 3, 4298-4311. [CrossRef]

138. Jurk, K.; Kehrel, B.E. Platelets: Physiology and biochemistry. Semin. Thromb. Hemost. 2005, 31, $381-392$. [CrossRef]

139. Huttner, K.M.; Bevins, C.L. Antimicrobial peptides as mediators of epithelial host defense. Pediatric Res. 1999, 45, 785-794. [CrossRef]

140. Horn, M.; Bertling, A.; Brodde, M.F.; Muller, A.; Roth, J.; Van Aken, H.; Jurk, K.; Heilmann, C.; Peters, G.; Kehrel, B.E. Human neutrophil alpha-defensins induce formation of fibrinogen and thrombospondin-1 amyloid-like structures and activate platelets via glycoprotein IIb/IIIa. J. Thromb. Haemost. JTH 2012, 10, 647-661. [CrossRef]

141. Abu-Fanne, R.; Stepanova, V.; Litvinov, R.I.; Abdeen, S.; Bdeir, K.; Higazi, M.; Maraga, E.; Nagaswami, C.; Mukhitov, A.R.; Weisel, J.W.; et al. Neutrophil alpha-defensins promote thrombosis in vivo by altering fibrin formation, structure, and stability. Blood 2019, 133, 481-493. [CrossRef] [PubMed] 
142. Berridge, M.J.; Bootman, M.D.; Roderick, H.L. Calcium signalling: Dynamics, homeostasis and remodelling. Nat. Rev. Mol. Cell Biol. 2003, 4, 517-529. [CrossRef] [PubMed]

143. Rink, T.; Sage, S. Calcium signaling in human platelets. Annu. Rev. Physiol. 1990, 52, 431-449. [CrossRef] [PubMed]

144. Hathaway, D.R.; Adelstein, R.S. Human platelet myosin light chain kinase requires the calcium-binding protein calmodulin for activity. Proc. Natl. Acad. Sci. USA 1979, 76, 1653-1657. [CrossRef]

145. Gerrard, J.M.; White, J.G.; Peterson, D.A. The platelet dense tubular system: Its relationship to prostaglandin synthesis and calcium flux. Thromb. Haemost. 1978, 40, 224-231. [CrossRef]

146. Rosado, J. Acidic Ca2+ stores in platelets. Cell Calcium 2011, 50, 168-174. [CrossRef]

147. Tanabe, Y.; Masu, M.; Ishii, T.; Shigemoto, R.; Nakanishi, S. A family of metabotropic glutamate receptors. Neuron 1992, 8, 169-179. [CrossRef]

148. Chatterton, J.E.; Awobuluyi, M.; Premkumar, L.S.; Takahashi, H.; Talantova, M.; Shin, Y.; Cui, J.; Tu, S.; Sevarino, K.A.; Nakanishi, N. Excitatory glycine receptors containing the NR3 family of NMDA receptor subunits. Nature 2002, 415, 793-798. [CrossRef]

149. Chen, B.-S.; Roche, K.W. Regulation of NMDA receptors by phosphorylation. Neuropharmacology 2007, 53, 362-368. [CrossRef]

150. Morrell, C.N.; Sun, H.; Ikeda, M.; Beique, J.-C.; Swaim, A.M.; Mason, E.; Martin, T.V.; Thompson, L.E.; Gozen, O.; Ampagoomian, D.; et al. Glutamate mediates platelet activation through the AMPA receptor. J. Exp. Med. 2008, 205, 575-584. [CrossRef]

151. Hitchcock, I.S.; Skerry, T.M.; Howard, M.R.; Genever, P.G. NMDA receptor-mediated regulation of human megakaryocytopoiesis. Blood 2003, 102, 1254-1259. [CrossRef]

152. Kalev-Zylinska, M.L.; Green, T.N.; Morel-Kopp, M.-C.; Sun, P.P.; Park, Y.-E.; Lasham, A.; During, M.J.; Ward, C.M. N-methyl-D-aspartate receptors amplify activation and aggregation of human platelets. Thromb. Res. 2014, 133, 837-847. [CrossRef]

153. Green, T.N.; Hamilton, J.R.; Morel-Kopp, M.-C.; Zheng, Z.; Chen, T.-Y.T.; Hearn, J.I.; Sun, P.P.; Flanagan, J.U.; Young, D.; Barber, P.A.; et al. Inhibition of NMDA receptor function with an anti-GluN1-S2 antibody impairs human platelet function and thrombosis. Platelets 2017, 28, 799-811. [CrossRef] [PubMed]

154. Panchina, Y.; Kelmanson, I.; Matz, M.; Lukyanov, K.; Usman, N.; Lukyanov, S. A ubiquitous family of putative gap junction molecules. Curr. Biol. 2000, 10, R473-R474. [CrossRef]

155. Bruzzone, R.; Hormuzdi, S.G.; Barbe, M.T.; Herb, A.; Monyer, H. Pannexins, a family of gap junction proteins expressed in brain. Proc. Natl. Acad. Sci. USA 2003, 100, 13644-13649. [CrossRef] [PubMed]

156. Taylor, K.; Wright, J.; Vial, C.; Evans, R.; Mahaut-Smith, M. Amplification of human platelet activation by surface pannexin-1 channels. J. Thromb. Haemost. 2014, 12, 987-998. [CrossRef]

157. Molica, F.; Morel, S.; Meens, M.J.; Denis, J.-F.; Bradfield, P.F.; Penuela, S.; Zufferey, A.; Monyer, H.; Imhof, B.A.; Chanson, M. Functional role of a polymorphism in the Pannexin1 gene in collageninduced platelet aggregation. Thromb. Haemost. 2015, 114, 325-336. [CrossRef] [PubMed]

158. Molica, F.; Meens, M.J.; Pelli, G.; Hautefort, A.; Emre, Y.; Imhof, B.A.; Fontana, P.; Scemes, E.; Morel, S.; Kwak, B.R. Selective inhibition of Panx1 channels decreases hemostasis and thrombosis in vivo. Thromb. Res. 2019, 183, 56-62. [CrossRef] [PubMed]

159. Li, S.; Bjelobaba, I.; Stojilkovic, S.S. Interactions of Pannexin1 channels with purinergic and NMDA receptor channels. Biochimica et biophysica acta. Biomembranes 2018, 1860, 166-173. [CrossRef]

160. Weilinger, N.L.; Lohman, A.W.; Rakai, B.D.; Ma, E.M.; Bialecki, J.; Maslieieva, V.; Rilea, T.; Bandet, M.V.; Ikuta, N.T.; Scott, L. Metabotropic NMDA receptor signaling couples Src family kinases to pannexin-1 during excitotoxicity. Nat. Neurosci. 2016, 19, 432-442. [CrossRef]

161. Siller-Matula, J.M.; Trenk, D.; Schror, K.; Gawaz, M.; Kristensen, S.D.; Storey, R.F.; Huber, K.; EPA. Response variability to P2Y12 receptor inhibitors: Expectations and reality. JACC Cardiovasc. Interv. 2013, 6, 1111-1128. [CrossRef] [PubMed]

162. Armaganijan, L.V.; Alexander, K.P.; Huang, Z.; Tricoci, P.; Held, C.; Van de Werf, F.; Armstrong, P.W.; Aylward, P.E.; White, H.D.; Moliterno, D.J.; et al. Effect of age on efficacy and safety of vorapaxar in patients with non-ST-segment elevation acute coronary syndrome: Insights from the Thrombin Receptor Antagonist for Clinical Event Reduction in Acute Coronary Syndrome (TRACER) trial. Am. Heart. J. 2016, 178, 176-184. [CrossRef] [PubMed] 
163. Magnani, G.; Bonaca, M.P.; Braunwald, E.; Dalby, A.J.; Fox, K.A.; Murphy, S.A.; Nicolau, J.C.; Oude Ophuis, T.; Scirica, B.M.; Spinar, J.; et al. Efficacy and safety of vorapaxar as approved for clinical use in the United States. J. Am. Heart Assoc. 2015, 4, e001505. [CrossRef] [PubMed]

164. Serebruany, V.L.; Fortmann, S.D. The FDA report on vorapaxar in the elderly: A convoluted dilemma. Int. J. Cardiol. 2015, 201, 601-603. [CrossRef]

165. Serebruany, V.L.; Tomek, A.; Pokov, A.N.; Kim, M.H. Clopidogrel, prasugrel, ticagrelor or vorapaxar in patients with renal impairment: Do we have a winner? Expert Rev. Cardiovasc. Ther. 2015, 13, 1333-1344. [CrossRef]

166. Bonaca, M.P.; Bhatt, D.L.; Steg, P.G.; Storey, R.F.; Cohen, M.; Im, K.; Oude Ophuis, T.; Budaj, A.; Goto, S.; Lopez-Sendon, J.; et al. Ischaemic risk and efficacy of ticagrelor in relation to time from P2Y12 inhibitor withdrawal in patients with prior myocardial infarction: Insights from PEGASUS-TIMI 54. Eur. Heart J. 2016, 37, 1133-1142. [CrossRef]

167. Parker, W.A.; Storey, R.F. Long-term antiplatelet therapy following myocardial infarction: Implications of PEGASUS-TIMI 54. Heart 2016, 102, 783-789. [CrossRef]

168. Kedhi, E.; Fabris, E.; van der Ent, M.; Buszman, P.; von Birgelen, C.; Roolvink, V.; Zurakowski, A.; Schotborgh, C.E.; Hoorntje, J.C.A.; Eek, C.H.; et al. Six months versus 12 months dual antiplatelet therapy after drug-eluting stent implantation in ST-elevation myocardial infarction (DAPT-STEMI): Randomised, multicentre, non-inferiority trial. BMJ 2018, 363, k3793. [CrossRef]

169. Watanabe, H.; Domei, T.; Morimoto, T.; Natsuaki, M.; Shiomi, H.; Toyota, T.; Ohya, M.; Suwa, S.; Takagi, K.; Nanasato, M.; et al. Effect of 1-Month Dual Antiplatelet Therapy Followed by Clopidogrel vs 12-Month Dual Antiplatelet Therapy on Cardiovascular and Bleeding Events in Patients Receiving PCI: The STOPDAPT-2 Randomized Clinical Trial. JAMA 2019, 321, 2414-2427. [CrossRef]

170. Costa, F.; van Klaveren, D.; James, S.; Heg, D.; Raber, L.; Feres, F.; Pilgrim, T.; Hong, M.K.; Kim, H.S.; Colombo, A.; et al. Derivation and validation of the predicting bleeding complications in patients undergoing stent implantation and subsequent dual antiplatelet therapy (PRECISE-DAPT) score: A pooled analysis of individual-patient datasets from clinical trials. Lancet 2017, 389, 1025-1034. [CrossRef]

171. Helft, G.; Steg, P.G.; Le Feuvre, C.; Georges, J.L.; Carrie, D.; Dreyfus, X.; Furber, A.; Leclercq, F.; Eltchaninoff, H.; Falquier, J.F.; et al. Stopping or continuing clopidogrel 12 months after drug-eluting stent placement: The OPTIDUAL randomized trial. Eur. Heart J. 2016, 37, 365-374. [CrossRef] [PubMed]

172. Wallentin, L. Commentary on the OPTIDUAL trial results: How to optimise prolonged dual antiplatelet treatment and independent randomised clinical trials. Eur. Heart J. 2016, 37, 375-377. [CrossRef] [PubMed]

173. Darmon, A.; Bhatt, D.L.; Elbez, Y.; Aboyans, V.; Anand, S.; Bosch, J.; Branch, K.R.; Connolly, S.J.; Dyal, L.; Eikelboom, J.W.; et al. External applicability of the COMPASS trial: An analysis of the reduction of atherothrombosis for continued health (REACH) registry. Eur. Heart J. 2018, 39, 750-757a. [CrossRef]

174. Bhatt, D.L.; Eikelboom, J.W.; Connolly, S.J.; Steg, P.G.; Anand, S.S.; Verma, S.; Branch, K.R.H.; Probstfield, J.; Bosch, J.; Shestakovska, O.; et al. Role of Combination Antiplatelet and Anticoagulation Therapy in Diabetes Mellitus and Cardiovascular Disease: Insights From the COMPASS Trial. Circulation 2020, 141, 1841-1854. [CrossRef]

175. Hernandez, J.L.; Lozano, F.S.; Riambau, V.; Almendro-Delia, M.; Cosin-Sales, J.; Bellmunt-Montoya, S.; Garcia-Alegria, J.; Garcia-Moll, X.; Gomez-Doblas, J.J.; Gonzalez-Juanatey, J.R.; et al. Reducing residual thrombotic risk in patients with peripheral artery disease: Impact of the COMPASS trial. Drugs Context 2020, 9. [CrossRef]

176. Ohman, E.M.; Roe, M.T.; Steg, P.G.; James, S.K.; Povsic, T.J.; White, J.; Rockhold, F.; Plotnikov, A.; Mundl, H.; Strony, J.; et al. Clinically significant bleeding with low-dose rivaroxaban versus aspirin, in addition to P2Y12 inhibition, in acute coronary syndromes (GEMINI-ACS-1): A double-blind, multicentre, randomised trial. Lancet 2017, 389, 1799-1808. [CrossRef]

177. Anand, S.S.; Bosch, J.; Eikelboom, J.W.; Connolly, S.J.; Diaz, R.; Widimsky, P.; Aboyans, V.; Alings, M.; Kakkar, A.K.; Keltai, K.; et al. Rivaroxaban with or without aspirin in patients with stable peripheral or carotid artery disease: An international, randomised, double-blind, placebo-controlled trial. Lancet 2018, 391, 219-229. [CrossRef]

178. Shyamkumar, K.; Hirsh, J.; Bhagirath, V.C.; Sinha, S.; Xu, K.; Ginsberg, J.S.; Diaz, R.; Eikelboom, J.W.; Chan, N.C. Mortality benefit in the COMPASS trial: Is it related to superior statistical power or better efficacy and safety? Future Cardiol. 2020. [CrossRef] 
179. Pirlet, C.; Legrand, V.; Nyssen, A.; Pierard, L.; Gach, O. Duration of dual anti-platelet therapy-State of the art after the DAPT and PEGASUS-TIMI 54 trials. Acta Cardiol. 2017, 72, 256-264. [CrossRef]

180. McFadyen, J.D.; Schaff, M.; Peter, K. Current and future antiplatelet therapies: Emphasis on preserving haemostasis. Nat. Rev. Cardiol. 2018, 15, 181-191. [CrossRef]

181. Jackson, S.P.; Schoenwaelder, S.M.; Goncalves, I.; Nesbitt, W.S.; Yap, C.L.; Wright, C.E.; Kenche, V.; Anderson, K.E.; Dopheide, S.M.; Yuan, Y.; et al. PI 3-kinase p110beta: A new target for antithrombotic therapy. Nat. Med. 2005, 11, 507-514. [CrossRef] [PubMed]

182. Gilio, K.; Harper, M.T.; Cosemans, J.M.; Konopatskaya, O.; Munnix, I.C.; Prinzen, L.; Leitges, M.; Liu, Q.; Molkentin, J.D.; Heemskerk, J.W.; et al. Functional divergence of platelet protein kinase C (PKC) isoforms in thrombus formation on collagen. J. Biol. Chem. 2010, 285, 23410-23419. [CrossRef] [PubMed]

183. Harper, M.T.; Poole, A.W. PKC inhibition markedly enhances Ca2+ signaling and phosphatidylserine exposure downstream of protease-activated receptor-1 but not protease-activated receptor-4 in human platelets. J. Thromb. Haemost. JTH 2011, 9, 1599-1607. [CrossRef]

184. Moore, S.F.; van den Bosch, M.T.; Hunter, R.W.; Sakamoto, K.; Poole, A.W.; Hers, I. Dual regulation of glycogen synthase kinase 3 (GSK3)alpha/beta by protein kinase C (PKC)alpha and Akt promotes thrombin-mediated integrin alphaIlbbeta3 activation and granule secretion in platelets. J. Biol. Chem. 2013, 288, 3918-3928. [CrossRef]

185. Tullemans, B.M.E.; Heemskerk, J.W.M.; Kuijpers, M.J.E. Acquired platelet antagonism: Off-target antiplatelet effects of malignancy treatment with tyrosine kinase inhibitors. J. Thromb. Haemost. JTH 2018, 16, 1686-1699. [CrossRef] [PubMed]

186. Busygina, K.; Jamasbi, J.; Seiler, T.; Deckmyn, H.; Weber, C.; Brandl, R.; Lorenz, R.; Siess, W. Oral Bruton tyrosine kinase inhibitors selectively block atherosclerotic plaque-triggered thrombus formation in humans. Blood 2018, 131, 2605-2616. [CrossRef] [PubMed]

187. Schwarz, M.; Katagiri, Y.; Kotani, M.; Bassler, N.; Loeffler, C.; Bode, C.; Peter, K. Reversibility versus persistence of GPIIb/IIIa blocker-induced conformational change of GPIIb/IIIa (alphaIIbbeta3, CD41/CD61). J. Pharmacol. Exp. Ther. 2004, 308, 1002-1011. [CrossRef] [PubMed]

188. Hagemeyer, C.E.; Peter, K. Targeting the platelet integrin GPIIb/IIIa. Curr. Pharm. Des. 2010, 16, 4119-4133. [CrossRef] [PubMed]

189. Shen, B.; Zhao, X.; O’Brien, K.A.; Stojanovic-Terpo, A.; Delaney, M.K.; Kim, K.; Cho, J.; Lam, S.C.; Du, X. A directional switch of integrin signalling and a new anti-thrombotic strategy. Nature 2013, 503, 131-135. [CrossRef]

190. Armstrong, P.C.; Peter, K. GPIIb/IIIa inhibitors: From bench to bedside and back to bench again. Thromb. Haemost. 2012, 107, 808-814. [CrossRef]

191. Ziegler, M.; Hohmann, J.D.; Searle, A.K.; Abraham, M.K.; Nandurkar, H.H.; Wang, X.; Peter, K. A single-chain antibody-CD39 fusion protein targeting activated platelets protects from cardiac ischaemia/reperfusion injury. Eur. Heart J. 2018, 39, 111-116. [CrossRef] [PubMed]

192. Hohmann, J.D.; Wang, X.; Krajewski, S.; Selan, C.; Haller, C.A.; Straub, A.; Chaikof, E.L.; Nandurkar, H.H.; Hagemeyer, C.E.; Peter, K. Delayed targeting of CD39 to activated platelet GPIIb/IIIa via a single-chain antibody: Breaking the link between antithrombotic potency and bleeding? Blood 2013, 121, 3067-3075. [CrossRef] [PubMed]

193. Granja, T.; Korner, A.; Gluck, C.; Hohmann, J.D.; Wang, X.; Kohler, D.; Streissenberger, A.; Nandurkar, H.H.; Mirakaj, V.; Rosenberger, P.; et al. Targeting CD39 Toward Activated Platelets Reduces Systemic Inflammation and Improves Survival in Sepsis: A Preclinical Pilot Study. Crit. Care Med. 2019, 47, e420-e427. [CrossRef] [PubMed]

194. Samudra, A.N.; Dwyer, K.M.; Selan, C.; Freddi, S.; Murray-Segal, L.; Nikpour, M.; Hickey, M.J.; Peter, K.; Robson, S.C.; Sashindranath, M.; et al. CD39 and CD73 activity are protective in a mouse model of antiphospholipid antibody-induced miscarriages. J. Autoimmun. 2018, 88, 131-138. [CrossRef] [PubMed]

195. Ungerer, M.; Rosport, K.; Bultmann, A.; Piechatzek, R.; Uhland, K.; Schlieper, P.; Gawaz, M.; Munch, G. Novel antiplatelet drug revacept (Dimeric Glycoprotein VI-Fc) specifically and efficiently inhibited collagen-induced platelet aggregation without affecting general hemostasis in humans. Circulation 2011, 123, 1891-1899. [CrossRef] [PubMed] 
196. Nylander, S.; Kull, B.; Bjorkman, J.A.; Ulvinge, J.C.; Oakes, N.; Emanuelsson, B.M.; Andersson, M.; Skarby, T.; Inghardt, T.; Fjellstrom, O.; et al. Human target validation of phosphoinositide 3-kinase (PI3K)beta: Effects on platelets and insulin sensitivity, using AZD6482 a novel PI3Kbeta inhibitor. J. Thromb. Haemost. JTH 2012, 10, 2127-2136. [CrossRef]

197. Stopa, J.D.; Neuberg, D.; Puligandla, M.; Furie, B.; Flaumenhaft, R.; Zwicker, J.I. Protein disulfide isomerase inhibition blocks thrombin generation in humans by interfering with platelet factor V activation. JCI Insight 2017, 2, e89373. [CrossRef]

198. Jurk, K.; Lahav, J.; Van Aken, H.; Brodde, M.F.; Nofer, J.R.; Kehrel, B.E. Extracellular protein disulfide isomerase regulates feedback activation of platelet thrombin generation via modulation of coagulation factor binding. J. Thromb. Haemost. JTH 2011, 9, 2278-2290. [CrossRef]

199. Moeckel, D.; Jeong, S.S.; Sun, X.; Broekman, M.J.; Nguyen, A.; Drosopoulos, J.H.; Marcus, A.J.; Robson, S.C.; Chen, R.; Abendschein, D. Optimizing human apyrase to treat arterial thrombosis and limit reperfusion injury without increasing bleeding risk. Sci. Transl. Med. 2014, 6, 248ra105. [CrossRef]

200. Tardif, J.C.; Tanguay, J.F.; Wright, S.R.; Duchatelle, V.; Petroni, T.; Gregoire, J.C.; Ibrahim, R.; Heinonen, T.M.; Robb, S.; Bertrand, O.F.; et al. Effects of the P-selectin antagonist inclacumab on myocardial damage after percutaneous coronary intervention for non-ST-segment elevation myocardial infarction: Results of the SELECT-ACS trial. J. Am. Coll. Cardiol. 2013, 61, 2048-2055. [CrossRef]

201. Oikonomou, E.; Leopoulou, M.; Theofilis, P.; Antonopoulos, A.S.; Siasos, G.; Latsios, G.; Mystakidi, V.C.; Antoniades, C.; Tousoulis, D. A link between inflammation and thrombosis in atherosclerotic cardiovascular diseases: Clinical and therapeutic implications. Atherosclerosis 2020, 309, 16-26. [CrossRef] [PubMed]

202. d'Alessandro, E.; Becker, C.; Bergmeier, W.; Bode, C.; Bourne, J.H.; Brown, H.; Buller, H.R.; Ten Cate-Hoek, A.J.; Ten Cate, V.; van Cauteren, Y.J.M.; et al. Thrombo-Inflammation in Cardiovascular Disease: An Expert Consensus Document from the Third Maastricht Consensus Conference on Thrombosis. Thromb. Haemost. 2020, 120, 538-564. [CrossRef] [PubMed]

203. Rayes, J.; Bourne, J.H.; Brill, A.; Watson, S.P. The dual role of platelet-innate immune cell interactions in thrombo-inflammation. Res. Pract. Thromb. Haemost. 2020, 4, 23-35. [CrossRef]

204. Ridker, P.M.; Everett, B.M.; Thuren, T.; MacFadyen, J.G.; Chang, W.H.; Ballantyne, C.; Fonseca, F.; Nicolau, J.; Koenig, W.; Anker, S.D.; et al. Antiinflammatory Therapy with Canakinumab for Atherosclerotic Disease. N. Engl. J. Med. 2017, 377, 1119-1131. [CrossRef] [PubMed]

205. Muller, K.A.; Chatterjee, M.; Rath, D.; Geisler, T. Platelets, inflammation and anti-inflammatory effects of antiplatelet drugs in ACS and CAD. Thromb. Haemost. 2015, 114, 498-518. [CrossRef] [PubMed]

206. Tunjungputri, R.N.; Li, Y.; de Groot, P.G.; Dinarello, C.A.; Smeekens, S.P.; Jaeger, M.; Doppenberg-Oosting, M.; Cruijsen, M.; Lemmers, H.; Toenhake-Dijkstra, H.; et al. The Inter-Relationship of Platelets with Interleukin1beta-Mediated Inflammation in Humans. Thromb. Haemost. 2018, 118, 2112-2125. [CrossRef]

Publisher's Note: MDPI stays neutral with regard to jurisdictional claims in published maps and institutional affiliations.

(C) 2020 by the authors. Licensee MDPI, Basel, Switzerland. This article is an open access article distributed under the terms and conditions of the Creative Commons Attribution (CC BY) license (http://creativecommons.org/licenses/by/4.0/). 